\title{
Three Subtypes of $\alpha$-Bungarotoxin-Sensitive Nicotinic Acetylcholine Receptors Are Expressed in Chick Retina
}

\author{
Kent T. Keyser, ${ }^{1}$ Luiz R. G. Britto, ${ }^{3}$ Ralf Schoepfer, ${ }^{4}$ Paul Whiting, ${ }^{5}$ John Cooper, ${ }^{6}$ William Conroy, ${ }^{2}$ Agnieszka \\ Brozozowska-Prechtl, ${ }^{1}$ Harvey J. Karten, ${ }^{1}$ and Jon Lindstrom ${ }^{6}$ \\ Departments of ${ }^{1}$ Neurosciences and ${ }^{2} B i o l o g y$, University of California, San Diego, California 92093-0608, ${ }^{3}$ Department of \\ Physiology and Biophysics, Institute of Biomedical Sciences, Sao Paulo State University, 05508 Sao Paulo, Brazil, ${ }^{4} \mathrm{ZMBH}$, \\ 6900 Heidelberg, INF 282 Germany, ${ }^{5}$ Merck, Sharp and Dohme Laboratories, Harlow, CM20 2QR, England, and ${ }^{6}$ The \\ Institute of Neurological Sciences, University of Pennsylvania, Philadelphia, Pennsylvania 19104-6142
}

A recent report described the isolation of cDNA clones encoding $\alpha \mathbf{7}$ and $\alpha \mathbf{8}$ subunits of $\alpha$-bungarotoxin-sensitive nicotinic ACh receptors ( $\alpha$ BgtAChRs) from chick brain and demonstrated that they were related to, but distinct from, the $\alpha$ subunits of nicotinic ACh receptors (nAChRs) from muscles and neurons. Monoclonal antibodies against the two $\alpha \mathrm{BgtAChR}$ subunits were used to demonstrate that at least two subtypes are present in embryonic day 18 chicken brain. The predominant brain subtype contains $\alpha 7$ subunits, while a minor subtype contains both $\alpha 7$ and $\alpha 8$ subunits. Both subtypes may also contain other subunits. Here we report the results of immune precipitation studies and immunohistochemical studies of $\alpha$ BgtAChRs in the chick retina. In addition to the two subtypes found in brain, a new $\alpha$ BgtAChR subtype that contains $\alpha 8$ subunits, but not $\alpha 7$ subunits, was identified and was found to be the major subtype in chick retina. This subtype has a lower affinity for $\alpha$-bungarotoxin ( $\alpha$ Bgt) than does the subtype containing only $\alpha 7$ subunits. Small amounts of this $\alpha \mathbf{8}$ subtype were also detected in brain by labeling with higher concentrations of ${ }^{125} \mid-\alpha$ Bgt than had been used previously. The subtype containing only $\alpha 7$ subunits comprised $14 \%$ of the $\alpha$ BgtAChRs in hatchling chick retina. The subtype containing $\alpha 8$ subunits (but no $\alpha 7$ subunits) accounted for $69 \%$, and the $\alpha 7 \alpha 8$ subtype accounted for $17 \%$. Amacrine, bipolar, and ganglion cells displayed $\alpha 8$ subunit immunoreactivity, and a complex pattern of labeling was evident in both the inner and outer plexiform layers. In contrast, only amacrine and ganglion cells exhibited $\alpha 7$ subunit immunoreactivity, and the pattern of $\alpha 7$ subunit labeling in the inner plexiform layer differed from that of $\alpha 8$ subunit labeling. These disparities suggest that the $\alpha$ BgtAChR sub-

\footnotetext{
Received May 1, 1992; revised July 15, 1992; accepted July 21, 1992.

This work was supported by EY07845 (K.T.K.) and EY06890 (H.J.K.). J.L. was supported by NSI 1323 and grants from the Muscular Dystrophy Association, the Council for Tobacco Research, and the Council for Smokeless Tobacco Research. L.R.G.B. was supported by FAPESP, CNPq, and Contract USP/BID (Brazil), and by the Fogarty International Center. R.S. was supported by a fellowship from Boehringer Ingelheim Fonds. We thank Kevin Cox for reviewing the manuscript and assistance with illustrations and Thomas Hughes for his comments on the manuscript. We also thank Dania Hammassaki-Britto for assistance with the figures.

Correspondence should be addressed to Kent T. Keyser, Department of Neurosciences, 0608, University of California at San Diego, San Diego, CA 920930608.

Copyright (C) 1993 Society for Neuroscience $0270-6474 / 93 / 130442-13 \$ 05.00 / 0$
}

units are differentially expressed by different populations of retinal neurons. In addition, the distribution of $\alpha$ BgtAChR subunit immunoreactivity was found to differ from that of $\alpha$-Bgt-insensitive nAChR subunits.

[Key words: ACh, bungarotoxin, nicotinic ACh receptors, receptors, neurotransmitters]

$\mathrm{ACh}$ is known to act as a neurotransmitter in the vertebrate retina. Physiological studies have shown that nicotine, $\mathrm{ACh}$, and $\mathrm{AChE}$ inhibitors can have profound affects on the response properties of many ganglion cells, including those that display directional selectivity (Noell and Lasansky, 1959; Straschill, 1968; Ames and Pollen, 1969; Straschill and Perwein, 1973; Masland and Ames, 1976; Ariel and Daw, 1982a,b; McReynolds and Miyachi, 1986). The availability of antisera directed against $\mathrm{ChAT}$, the enzyme responsible for $\mathrm{ACh}$ synthesis, has allowed the precise identification and characterization of cholinergic cells in the inner nuclear layer (INL) and ganglion cell layer (GCL) of the retina (for a review, see Vaney, 1990). In contrast, the identification and study of the cholinoceptive neurons in the retina has been more problematic.

Initial attempts to identify the cholinoceptive cells relied upon the localization of radioactively labeled or peroxidase-conjugated $\alpha$-bungarotoxin ( $\alpha \mathrm{Bgt})$. $\alpha \mathrm{Bgt}$ is a protein from snake venom that binds with high affinity to the $\mathrm{ACh}$ binding site of the nicotinic ACh receptors ( $\mathrm{AAChRs}$ ) from muscle. Thus, when high-affinity $\alpha \mathrm{Bgt}$ binding was found in the retina, this binding was assumed to represent functional nAChRs. Various investigators reported that $\alpha \mathrm{Bgt}$ bound specifically and with high affinity to sites in both the inner plexiform layer (IPL) and outer plexiform layer (OPL) of goldfish, chick, pigeon, turtle, and rabbit retina (Vogel and Nirenberg, 1976; Yazulla and Schmidt, 1976, 1977; Vogel et al., 1977; Schwartz and Bok, 1979; Zucker and Yazulla, 1982). However, the resolution of these methods was too low to permit the identification of all of the cell types that contained the $\alpha \mathrm{Bgt}$ binding sites. Subsequently, other investigators showed that (1) there were neuronal $\mathrm{nAChRs}$ that did not bind $\alpha \mathrm{Bgt}$, and (2) cells that had both $\mathrm{nAChRs}$ and $\alpha \mathrm{Bgt}$ binding sites exhibited ACh-gated cation channels that were not blocked by $\alpha$ Bgt (Patrick and Stallcup, 1977; Carbonetto et al., 1978; Ravdin and Berg, 1979; Chiappinelli, 1985; Whiting and Lindstrom, 1986a,b, 1987; Boulter et al., 1987; Lipton et al., 1987; Ballivet et al., 1988). Furthermore, $\alpha$ Bgt binding sites on 


\begin{tabular}{|c|c|c|c|c|}
\hline \multirow[b]{2}{*}{$\mathrm{mAb}$} & \multicolumn{2}{|c|}{ Specificity $^{a}$} & \multirow[b]{2}{*}{ Immunogen $^{b}$} & \multirow{2}{*}{$\begin{array}{l}\text { Immunoglobulin } \\
\text { type }\end{array}$} \\
\hline & Subunit & Synthetic peptide binding & & \\
\hline 306 & $\alpha 7$ & $\alpha 7(380-400)$ & $\begin{array}{l}\text { Purified chicken brain } \\
\alpha \text { BgtAChR }\end{array}$ & Mouse IgGI \\
\hline 318 & $\alpha 7$ & $\alpha 7(380-400)$ & $\begin{array}{l}\text { Bacterially expressed } \\
\text { chicken } \alpha 7327-412\end{array}$ & Rat IgGi \\
\hline 308 & $\alpha 8$ & $\alpha 8(323-342)$ & $\begin{array}{l}\text { Bacterially expressed } \\
\text { chicken } \alpha 8293-435\end{array}$ & Rat IgG2B \\
\hline 305 & $\alpha 8$ & $\begin{array}{l}\text { None (absolutely } \\
\text { conformation } \\
\text { dependent) }\end{array}$ & $\begin{array}{l}\text { Purified chicken brain } \\
\quad \alpha \text { BgtAChR }\end{array}$ & Rat IgG2C \\
\hline
\end{tabular}

\footnotetext{
McLane et al. (1992).

${ }^{b}$ Schoepfer et al. (1990).
}

chick ciliary ganglion neurons were found only on pseudodendrites rather than at synaptic sites where $\mathrm{nAChRs}$ were localized (Jacob and Berg, 1983; Jacob et al., 1984). These findings suggested that $\alpha \mathrm{Bgt}$ binding sites did not represent functional nAChRs.

The availability of antibodies against, and cDNA probes for, structural and ligand binding subunits of $\mathrm{nAChRs}$ has greatly enhanced our ability to localize these proteins in the retina. Studies using monoclonal antibodies (mAbs) against the structural and $\mathrm{ACh}$ binding subunits have shown that populations of amacrine, ganglion, and displaced ganglion cells in the chick retina contain $\mathrm{nAChRs}$ and that the dendrites of these cells are in register with the dendrites of cholinergic amacrine cells (Keyser et al., 1988; Whiting et al., 1991).

Recently, chicken brain cDNA clones that encode two $\alpha$ subunits of the $\alpha \mathrm{Bgt}$-sensitive nAChRs ( $\alpha \mathrm{BgtAChRs)}$ were isolated (Schoepfer et al., 1990). These were originally designated $\alpha 1$ and $\alpha 2$ but are now referred to as $\alpha 7$ and $\alpha 8$ (see Britto et al., 1992). On the basis of the deduced amino acid sequences, Schoepfer et al. (1990) reported that $\alpha \mathrm{BgtAChRs}$ are members of the ligand-gated ion channel family that includes $n A C h R s$ from muscle and neurons and the $\mathrm{GABA}_{\mathrm{A}}$ and glycine receptors. The two $\alpha$ subunits were shown to be ligand binding subunits by the ability of corresponding synthetic peptides to bind $\alpha$ Bgt (McLane et al., 1991). mAbs were raised against native $\alpha \mathrm{BgtAChRs}$, and two bacterially expressed subunit fragments and the epitopes recognized by the $\mathrm{mAbs}$ were mapped with synthetic peptides (McLane et al., 1992). Studies using these mAbs demonstrated that in embryonic day 18 (E18) chick brain more than $75 \%$ of all $\alpha$ BgtAChRs have $\alpha 7$ subunits, but no $\alpha 8$ subunits, while roughly $15 \%$ of all $\alpha \mathrm{BgtAChRs}$ have both $\alpha 7$ and $\alpha 8$ subunits (Schoepfer et al., 1990).

Several lines of evidence suggest that some of the $\alpha$ BgtAChRs found in the nervous system may represent a new class of $\mathrm{ACh}$ gated ion channels. For example, $\alpha$ BgtAChRs affinity purified from chicken brains and reconstituted into planar lipid bilayers form carbamylcholine-gated cation channels that are blocked by $d$-tubocurarine (Gotti et al., 1991). Furthermore, Couturier et al. (1990) demonstrated that the $\alpha 7$ subunit, when injected into Xenopus oocytes, assembles into a homo-oligomeric channel that responds to $\mathrm{ACh}$ and nicotine. Chick ciliary ganglion neurons express large amounts of $\alpha 7$ (Vernallis et al., 1991) and exhibit $\mathrm{ACh}$-induced $\mathrm{Ca}^{2+}$ influx that can be blocked by $\alpha \mathrm{Bgt}$ (Vijayaraghavan et al., 1992).
We describe below the results of immune precipitation and immunohistochemical studies of $\alpha \mathrm{BgtAChRs}$ in the retinas of E1 8 and newly hatched chicks. We report the identification of a new $\alpha$ BgtAChR subtype containing $\alpha 8$, but not $\alpha 7$, subunits that is present in small quantities in chick brain but that constitutes the major subtype in chick retina. In addition, our immunohistochemical data demonstrate that (1) the distribution of $\alpha 7$ subunit immunoreactivity differs from that of $\alpha 8$ subunit immunoreactivity, and (2) the distribution of both $\alpha \mathrm{BgtAChR}$ subunits in the retina differs from the distribution of $\alpha$-Bgt-insensitive nAChRs.

\section{Materials and Methods}

White leghorn chicken eggs were obtained from MacIntyre Poultry (Lakeside, CA) and were housed in a humidified incubator at $37^{\circ} \mathrm{C}$. Following hatching, chicks were housed in a brooder and provided with food and water ad libitum. Twenty-five chicks were used for immunohistochemical analyses.

Tissue preparation. One or two days after hatching, the chicks were given an overdose of ketamine and xylazine and decapitated and the head was placed in a shallow dish of ice-cold $2 \%$ paraformaldehyde in $0.1 \mathrm{M}$ phosphate buffer ( $\mathrm{pH}$ 7.4). The eyes were immediately removed from the head, the antcrior polc of cach cyc was cut away, and the vitreous was removed as completely as possible. The eyes were immersed in ice-cold fixative for 4-6 hr and then placed in $0.1 \mathrm{M}$ phosphate buffer containing $30 \%$ sucrose for at least $14 \mathrm{hr}$ to minimize damage resulting from freezing.

Some of the eyecups were immersed in embedding medium, frozen, and sectioned $(10 \mu \mathrm{m})$ on a cryostat. Sections were collected on gelatincoated glass slides. Alternatively, the retina was removed from the eyecup, radial incisions were made, and the retina was flattened. The retina was then frozen and $25-40 \mu \mathrm{m}$ sections were cut parallel to the vitreal surface on a sliding microtome. Sections cut in this plane were processed "free floating" in small vials.

Immunohistochemistry. Four monoclonal antibodies (mAbs) were used in this study: $\mathrm{mAb} 305, \mathrm{mAb} 306, \mathrm{mAb} 308$, and $\mathrm{mAb} 318$. A complete description of the immunogen uscd to produce cach antibody is presented in Schoepfer et al. (1990), and synthetic peptide mapping of their epitopes is reported in McLane et al. (1992). Table 1 summarizes the properties of these mAbs.

Tissue sections were washed in three changes of phosphate buffer and then incubated with $\mathrm{mAb}$ diluted in a $0.1 \mathrm{M}$ sodium phosphate buffer solution containing $0.3 \%$ Triton X-100 for $12-24 \mathrm{hr}$. The primary mAbs were used at concentrations ranging from 10 to $20 \mathrm{nM}$.

Avidin-biotin labeling. Following incubation in $\mathrm{mAb}$, the sections were washed in three changes of phosphate buffer and incubated in a solution of biotinylated goat anti-rat or mouse IgG (Jackson Labs) diluted $1: 200$ in buffer containing $0.3 \%$ Triton $X-100$ for $1 \mathrm{hr}$. The sections were then washed and incubated in a mixture of biotin and avidinbound horseradish peroxidase diluted $1: 100$ in $0.3 \%$ Triton $X-100$ in 
phosphate buffer for $1 \mathrm{hr}$. After washing, the tissue was incubated in $0.05 \%$ diaminobenzidine in buffer for $15 \mathrm{~min}$. Hydrogen peroxide was then added to make a final concentration of $0.01 \%$, the dish was gently shaken, and after $15 \mathrm{~min}$ the tissue was washed in several changes of buffer and coverslips were applied.

Controls. The specificity of staining was verified by omission of the $\mathrm{mAb}$ or secondary antibody. In addition, in some instances the $\mathrm{mAb}$ was replaced by normal serum from the same species. In both cases specific staining was abolished.

Radioimunoassays of $\alpha$ BgtAChR subtypes. Detergent extracts of $\alpha \mathrm{BgtAChRs}$ from brains and retinas of embryonic day 18 and newly hatched chicks were prepared in the following manner. Brains and retinas were dissected from the animals and then frozen. The frozen tissues were thawed in $10 \mathrm{vol}$ of $50 \mathrm{~mm} \mathrm{Na}$ phosphate buffer ( $\mathrm{pH} 7.5), 1 \mathrm{M}$ $\mathrm{NaCl}, 5 \mathrm{~mm}$ EDTA, $5 \mathrm{~mm}$ EGTA, $2 \mathrm{~mm}$ phenylmethylsulfonyl fluoride, $5 \mathrm{~mm}$ benzamidine, and $5 \mathrm{~mm}$ iodoacetamide, and then homogenized on ice for $2 \mathrm{~min}$ at $15,000 \mathrm{rpm}$ with a Brinkman Polytron. After dilution with another 10 vol of buffer, the homogenate was centrifuged at 50,000 rpm in a Beckman 50.2 ti rotor for $30 \mathrm{~min}$ at $4^{\circ} \mathrm{C}$. The pellet was homogenized again in an equal volume of buffer, this time containing $50 \mathrm{~mm} \mathrm{NaCl}$, and centrifuged to extract soluble components further. The pellet was then extracted with 4 vol of $2 \%$ Triton $X-100,50 \mathrm{~mm}$ $\mathrm{NaCl}, 50 \mathrm{~mm} \mathrm{Na}$ phosphate buffer (pH 7.5), and the same mix of chelating agents and protease inhibitors used in the homogenization buffer. After initially disrupting for $15 \mathrm{sec}$ at $10,000 \mathrm{rpm}$ with a Brinkman Polytron, the resuspended pellet was shaken for $2 \mathrm{hr}$ at $4^{\circ} \mathrm{C}$. The mix was centrifuged at $50,000 \mathrm{rpm}$ in a Beckman 50.2 ti rotor at $4^{\circ} \mathrm{C}$ for $30 \mathrm{~min}$. The concentration of $\alpha \mathrm{BgtAChR}$ in the resulting supernatants was typically 3-5 nM.

The total amount of $\alpha$ BgtAChR in extracts was determined by an assay that depends upon the negative charge of $\alpha \mathrm{BgtAChRs}$ to bind to DEAE while positively charged ${ }^{125} \mathrm{I}-\alpha \mathrm{Bgt}$ does not. ${ }^{125} \mathrm{I}-\alpha \mathrm{Bgt}$ was iodinated to specific activities of $>6 \times 10^{17} \mathrm{cpm} / \mathrm{mol}$ as previously described (Lindstrom et al., 1981). Schmidt and Raftery (1973) initially used DEAE to measure AChRs, and the technique used here is a modification of that previously described by Whiting and Lindstrom (1986b). DE52 (Whatman) cquilibrated with $10 \mathrm{~mm} \mathrm{Na}$ phosphate buffer ( $\mathrm{pH} 7.5)$, $0.5 \%$ Triton X-100 (150 $\mu$ l packed volume) was loaded in USB Compact Reaction Columns in triplicate. Extracts were labeled overnight at $4^{\circ} \mathrm{C}$ with $50 \mathrm{nM}{ }^{125}$ I- $\alpha$ Bgt with or without $10 \mathrm{~mm}$ nicotine as a negative control. Then, $10 \mu$ laliquots were diluted to $100 \mu \mathrm{l}$ in the $10 \mathrm{~mm}$ buffer and applied to the DE52. After $2 \mathrm{~min}$, the columns were washed four times with $500 \mu 1$ of buffer. The whole column was then counted and specific binding was determined by subtracting the negative control value (typically about $20-30 \%$ of total binding).

The total amount of $\alpha$ BgtAChRs and the affinity of the $\alpha 7$ and $\alpha 8$ subtypes for ${ }^{125} \mathrm{I}-\alpha \mathrm{Bgt}$ were determined by a solid-phase radioimmunoassay using mAb-coated microwells. Protein $\mathrm{G}$ affinity column-purified $\mathrm{mAb} 305, \mathrm{mAb} 318$, or a mixture of the two, was coupled to Immulon 4 Removawells (Dynatech) by incubating $100 \mu \mathrm{l} /$ well of 40 $\mathrm{mg} / \mathrm{ml} \mathrm{mAb}$ in $10 \mathrm{~mm} \mathrm{Na}$ bicarbonate buffer $(\mathrm{pH} 8.8$ ) overnight at room temperature in a closed, humidified box. After three washes $(200 \mu l$ each), excess protein binding capacity of the wells was quenched with $200 \mu \mathrm{l}$ of $3 \%$ bovine serum albumin in $100 \mathrm{~mm} \mathrm{NaCl}, 10 \mathrm{~mm} \mathrm{Na}$ phosphate buffer ( $\mathrm{pH} 7.5$ ), and $0.05 \%$ Tween 20 for $2 \mathrm{hr}$. The wells were then washed three times with $200 \mu \mathrm{l}$ of the same buffer without albumin.

The total amount of $\alpha$ BgtAChR containing either $\alpha 7$ or $\alpha 8$ subunits was measured using a solid-phase assay in which the microwells were coated with a mixture of both $\mathrm{mAb} 305$ and $\mathrm{mAb} 318$. Triplicate aliquots of $0.1-10 \mu \mathrm{l}$ of extract in a total volume of $50 \mathrm{ml}$ of $10 \mathrm{~mm} \mathrm{Na}$ phosphate ( $\mathrm{pH} 7.5), 100 \mathrm{~mm} \mathrm{NaCl}, 10 \mathrm{~mm} \mathrm{NaN}_{3}$, and $0.5 \%$ Triton $\mathrm{X}-100$ were mixed in the wells with $50 \mu \mathrm{l}$ of buffer containing $100 \mathrm{~nm}$ ${ }^{125} \mathrm{I}-\alpha \mathrm{Bgt}$ to give a final concentration of $50 \mathrm{nM}{ }^{125} \mathrm{I}-\alpha \mathrm{Bgt}$. After overnight incubation at $4^{\circ} \mathrm{C}$ in a humidified box, the wells were washed three times with $200 \mu \mathrm{l}$ of $10 \mathrm{~mm} \mathrm{Na}$ phosphate (pH 7.5), $0.05 \%$ Tween 20 and then bound ${ }^{125}$ I was determined by gamma counting. In the solid-phase assays, binding of $\alpha \mathrm{BgtAChRs}$ to the wells was linear to $>2.5 \times 10^{13}$ $\mathrm{mol} /$ well and background values were $<1 \%$ of the maximum labeling.

Affinity for $\alpha$ Bgt was measured separately for the $\alpha 7$ and $\alpha 8$ subtypes by solid-phase assays using extracts depleted of either all $\alpha$ BgtAChRs containing $\alpha 8$ or all of those containing $\alpha 7$. Extract from E18 retinas was depleted of $>99 \%$ of $\alpha 8$-containing $\alpha \mathrm{BgtAChRs}$ using purified $\mathrm{mAb}$ 305 coupled at $2 \mathrm{mg} / \mathrm{ml}$ of gel to Actigel ALD (Sterogene) according to the manufacturer's instructions. The mAb 305-coated beads at a ratio of beads to extract of $1: 7$ were incubated overnight at $4^{\circ} \mathrm{C}$ with gentle agitation, and then the beads were removed by brief centrifugation. Assays of $\alpha 7$-containing $\alpha \mathrm{BgtAChRs}$ used duplicate wells coated with $\mathrm{mAb} 318$ and blank wells from which the $\mathrm{mAb}$ was omitted. In each well, $50 \mu \mathrm{l}$ of extract depleted of $\alpha 8$ was mixed with $50 \mu \mathrm{l}$ of $0.1 \mathrm{M} \mathrm{NaCl}$, $10 \mathrm{~mm} \mathrm{NaN}$, and $0.5 \%$ Triton X-100 containing sufficient ${ }^{125}$ T- $\alpha$ Bgt to yield final concentrations of $0.1-16 \mathrm{~nm}$. After overnight incubation at $4^{\circ} \mathrm{C}$, the wells were washed three times with $200 \mu \mathrm{l}$ of $10 \mathrm{~mm} \mathrm{Na}$ phosphate ( $\mathrm{pH} 7.5$ ), $0.05 \%$ Tween 20 and then bound ${ }^{125} \mathrm{I}$ was determined by gamma counting. More than $97 \%$ of $\alpha 7$-containing $\alpha \mathrm{BgtAChR}$ was depleted from E18 retina extract by using mAb 318 coupled at $3 \mathrm{mg}$ ml of gel to Afligel $\mathrm{Hz}$ (Bio-Rad) according to the manufacturer's directions. The $\mathrm{mAb}$-coated beads were used for absorption in the same way as were the $\mathrm{mAb} 305$-coated beads. Assays of $\alpha 8$-containing $\alpha$ BgtAChRs used duplicate wells coated with mAb 305. In each well, $25 \mu \mathrm{l}$ of extract depleted of $\alpha 7$ was mixed with ${ }^{125} \mathbf{I}-\alpha \mathrm{Bgt}$ in $100 \mu \mathrm{l}$ reaction mixes similar to those for $\alpha 7$ assays but containing $1-75 \mathrm{nM}^{125} \mathrm{I}-\alpha \mathrm{Bgt}$.

The relative abundance of each $\alpha \mathrm{BgtAChR}$ subtype was determined by immune precipitation. Extracts were diluted to $0.5 \mathrm{~nm}$ in total $\alpha$ BgtAChR using $0.5 \%$ Triton X-100, $100 \mathrm{~mm} \mathrm{NaCl}, 10 \mathrm{~mm} \mathrm{NaN}$, and $10 \mathrm{~mm} \mathrm{Na}$ phosphate buffer ( $\mathrm{pH} 7.5$ ), and labeled with 35 or $50 \mathrm{~nm}$ ${ }^{125} \mathrm{I}-\alpha \mathrm{Bgt}$. Triplicate $200 \mu \mathrm{I}$ aliquots containing the indicated amounts of $\mathrm{mAb} 308, \mathrm{mAb} 318$, or both, and $4 \mu \mathrm{l}$ of normal rat serum were incubated overnight at $4^{\circ} \mathrm{C}$. Then, $100 \mu \mathrm{l}$ of an appropriate dilution of goat anti-rat $\mathrm{IgG}$ was added for $4 \mathrm{hr}$. The samples were diluted with 1 ml of $0.5 \%$ Triton X-100 buffer and centrifuged in a Beckman Microfuge 12 for $8 \mathrm{~min}$. The pellets were washed twice using $1 \mathrm{ml}$ of buffer and recentrifugation before gamma counting. Blank values determined using only normal serum and no mAb were subtracted from each assay value.

\section{Results}

Immunohistochemical localization of $\alpha 7$ and $\alpha 8$ subunits revealed more $\alpha 8$ immunoreactivity than expected

mAbs 306 and 318 , which recognize two different epitopes on $\alpha 7$ subunits of $\alpha$ BgtAChRs, yielded identical patterns of labeling in hatchling chick retina (Fig. $1 A, C$ ). Similarly, mAbs 308 and 305 , which recognize two different epitopes on $\alpha 8$ subunits, yielded identical patterns of labeling (Fig. $1 B, D$ ). Examination of sections of hatchling retina stained with these $m$ Abs revealed that more $\alpha 8$ immunoreactivity was present than expected based upon previous immune precipitation studies of E18 brain. In these studies, only $15 \%$ of $\alpha$ BgtAChRs were found to contain $\alpha 8$ subunits (Schoepfer et al., 1990). Indeed, more $\alpha 8$ immunoreactivity was evident than $\alpha 7$ immunoreactivity. In view of these observations, immune precipitation assays to quantify the fraction of $\alpha$ BgtAChRs incorporating $\alpha 7, \alpha 8$, or both subunits were conducted with hatchling and embryonic retinas and brains.

$\alpha 7$-containing $\alpha B g t A C h R s$ have a higher affinity for $\alpha B g t$ than do those that contain $\alpha 8$ subunits

Binding of ${ }^{125} \mathrm{I}-\alpha \mathrm{Bgt}$ to $\alpha \mathrm{BgtAChRs}$ in detergent extracts from E18 retina was studied using a solid-phase radioimmunoassay. The $\alpha 7$ subtype and the newly discovered $\alpha 8$ subtype were studied separately. $\alpha$ BgtAChR subtypes containing only $\alpha 7$ subunits or only $\alpha 8$ subunits (in conjunction with some unknown complement of structural subunits), but not the subtype containing both $\alpha 7$ and $\alpha 8$ subunits, were prepared by absorbing detergent extracts of E18 retinas with either mAb 305 coupled to agarose to remove $\alpha \mathrm{BgtAChRs}$ containing $\alpha 8$ subunits or mAb 318 coupled to agarose to remove $\alpha \mathrm{BgtAChRs}$ containing $\alpha 7$ subunits. Figure 2 shows that the $\alpha 7$ subtype had relatively high affinity for ${ }^{125} \mathrm{I}-\alpha \mathrm{Bgt}\left(K_{D}=2.1 \times 10^{-9} \mathrm{M}\right)$ whereas the ${ }^{125} \mathrm{I}-\alpha \mathrm{Bgt}$ affinity of the $\alpha 8$ subtype was substantially lower $\left(K_{D}=17.2 \times\right.$ $\left.10^{-9} \mathrm{M}\right)$. Thus, the amount of $\alpha 8$ could be easily underestimated at the concentrations of ${ }^{125} \mathrm{I}-\alpha \mathrm{Bgt}$ typically used in such assays. In subsequent experiments ${ }^{125} \mathrm{I}-\alpha \mathrm{Bgt}$ was used at concentrations 

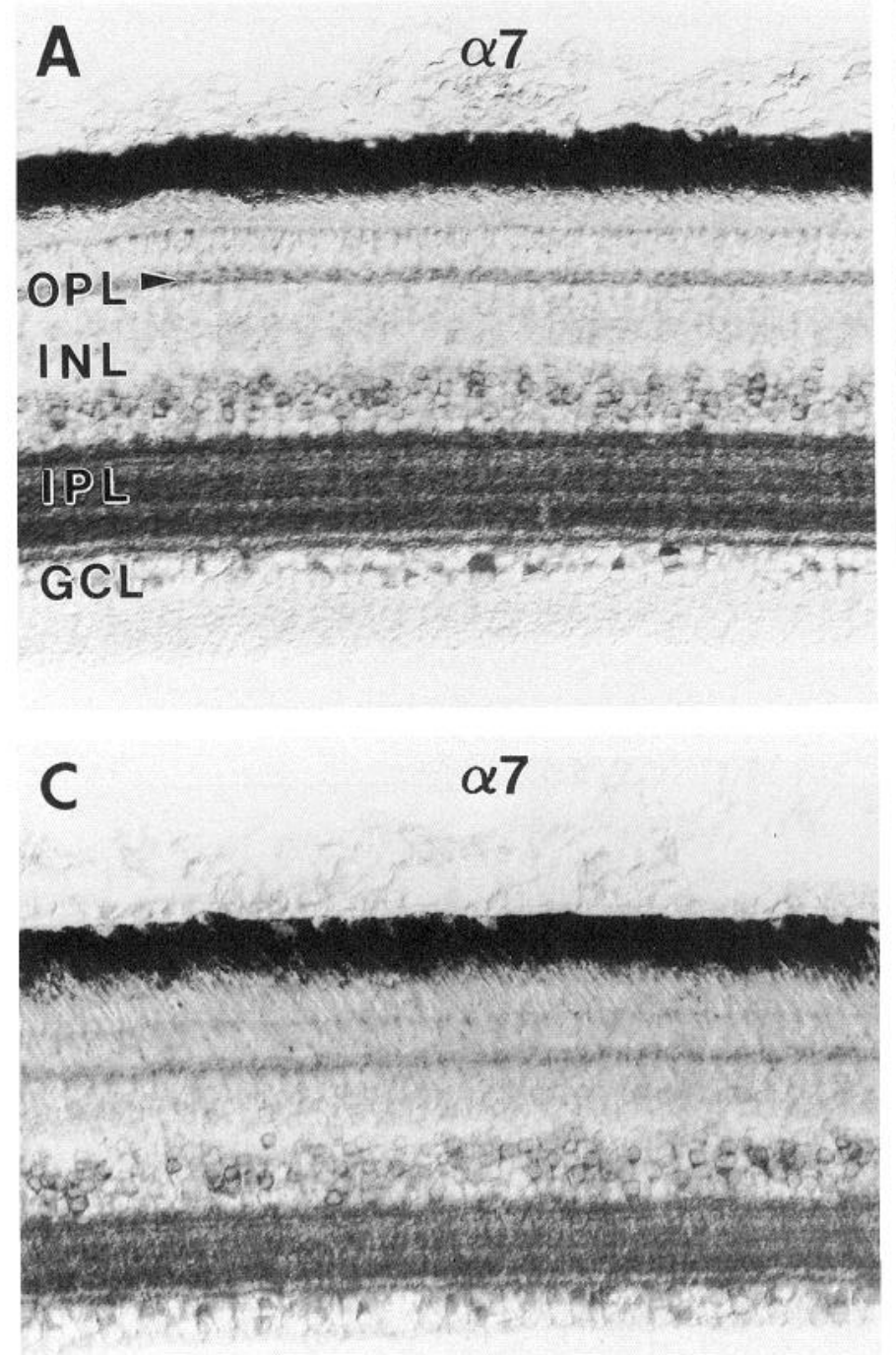
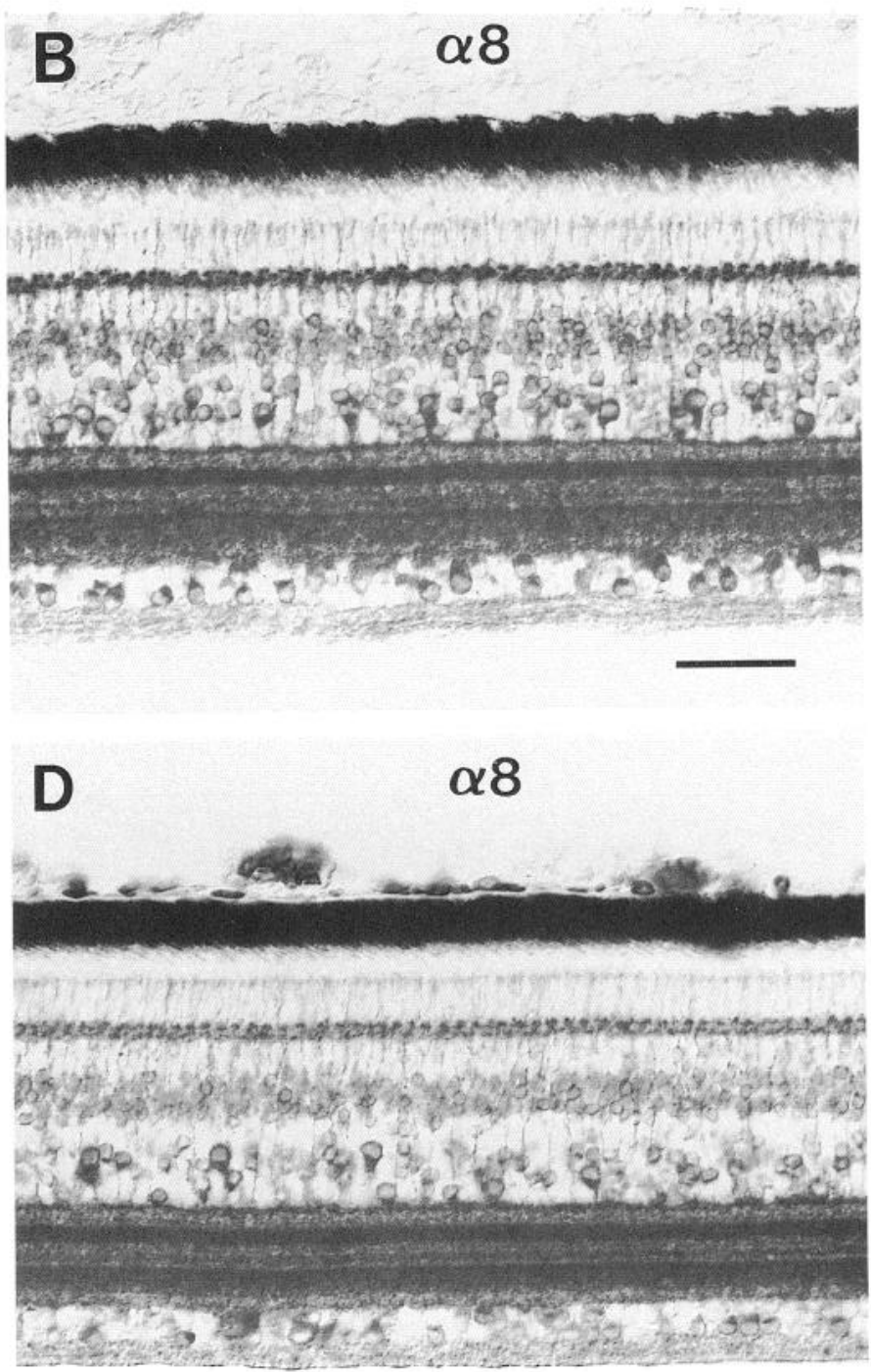

Figure 1. Photographs of transverse sections of chick retina illustrating the distribution of $\alpha$ BgtAChR immunoreactivity. The sections shown in $A$ and $C$ were processed using mAb 306 and mAb 318, respectively. These antibodies recognize two different epitopes on $\alpha 7$ subunits. The sections shown in $B$ and $D$ were processed using mAb 305 and mAb 308, respectively. These antibodies recognize different epitopes on $\alpha 8$ subunits. More $\alpha 8$ immunoreactivity was present than expected. Scale bar, $50 \mathrm{~mm}$.

sufficiently high to ensure complete labeling of the $\alpha 8$ subtype. The binding of ${ }^{125} \mathrm{I}-\alpha \mathrm{Bgt}$ to the $\alpha 7 \alpha 8$ subtype was not specifically studied.

\section{All specific binding of ${ }^{125} \mathrm{I}-\alpha \mathrm{Bg}$ t in brain and retina extracts is associated with $\alpha 7$ or $\alpha 8$ subunits}

The total number of binding sites for ${ }^{125} \mathrm{I}-\alpha \mathrm{Bgt}$ in detergent extracts of both retina and brain were determined using two assays. One assay used small DEAE columns to bind labeled aBgtAChRs. This assay was independent of the immunological properties of the protein and depended only upon the rather low isoelectric point (i.e., rather negative charge) of all known AChRs as compared to the highly positive charge of $\alpha$ Bgt. This is a very general assay that is not characterized by a high signal: noise ratio. The other assay was a solid-phase radioimmunoassay in which individual mAbs or a mixture of mAbs to $\alpha 7$ or $\alpha 8$ was used to bind $\alpha \mathrm{BgtAChRs}$ to microwells. This assay spe- cifically measures the immunologically identified subtypes and has a very high signal:noise ratio. Table 2 shows that even when ${ }^{125} \mathrm{I}-\alpha \mathrm{Bgt}$ was used at concentrations as high as $50 \mathrm{nM}$, essentially all of the ${ }^{125} \mathrm{I}-\alpha \mathrm{Bgt}$ binding in extracts can be accounted for by $\alpha$ BgtAChRs containing $\alpha 7$ subunits, $\alpha 8$ subunits, or a combination of the two.

Determination of the fraction of $\alpha$ BgtAChRs in brain and retina that contain $\alpha 7, \alpha 8$, or both subunits

The relative abundance of $\alpha \mathrm{BgtAChR}$ subtypes in both E18 and hatchling chick brains and retinas was determined by immune precipitation assays. The maximum fraction of the ${ }^{125} \mathrm{I}-$ $\alpha$ Bgt-labeled $\alpha$ BgtAChR that could be immunoprecipitated with mAbs specific for $\alpha 7$ or $\alpha 8$ subunits was determined as shown in Figure 3. The subunit composition calculated from such experiments is shown in Table 3 . Because of the high concentration of ${ }^{125} \mathrm{I}-\alpha \mathrm{Bgt}$ used, we were now able to detect low levels of a 
Figure 2. The $\alpha 7$ subtype of $\alpha \mathrm{Bgt}-$ AChR has higher affinity for $\alpha$ Bgt than does the $\alpha 8$ subtype. As described in the Materials and Methods, detergent extracts of E18 retina containing the $\alpha 7$ subtype were prepared by absorbing with $\mathrm{mAb}$ to $\alpha 8$, and extracts containing the $\alpha 8$ subtype were prepared by absorbing with $\mathrm{mAb}$ to $\alpha 7$. The binding of ${ }^{125} \mathrm{I}-\alpha$ Bgt to $\alpha$ BgtAChRs from these extracts was then measured using with mAbs specific for $\alpha 7$ or $\alpha 8$ subunits to bind the $\alpha$ BgtAChRs to microwells. The top panel illustrates binding data for the $\alpha 7$ subtype, and the bottom panel shows binding data for the $\alpha 8$ subtype. Both panels show the binding curve and an inset with a Scatchard plot of the binding curve used to determine the $K_{D}$ for binding.

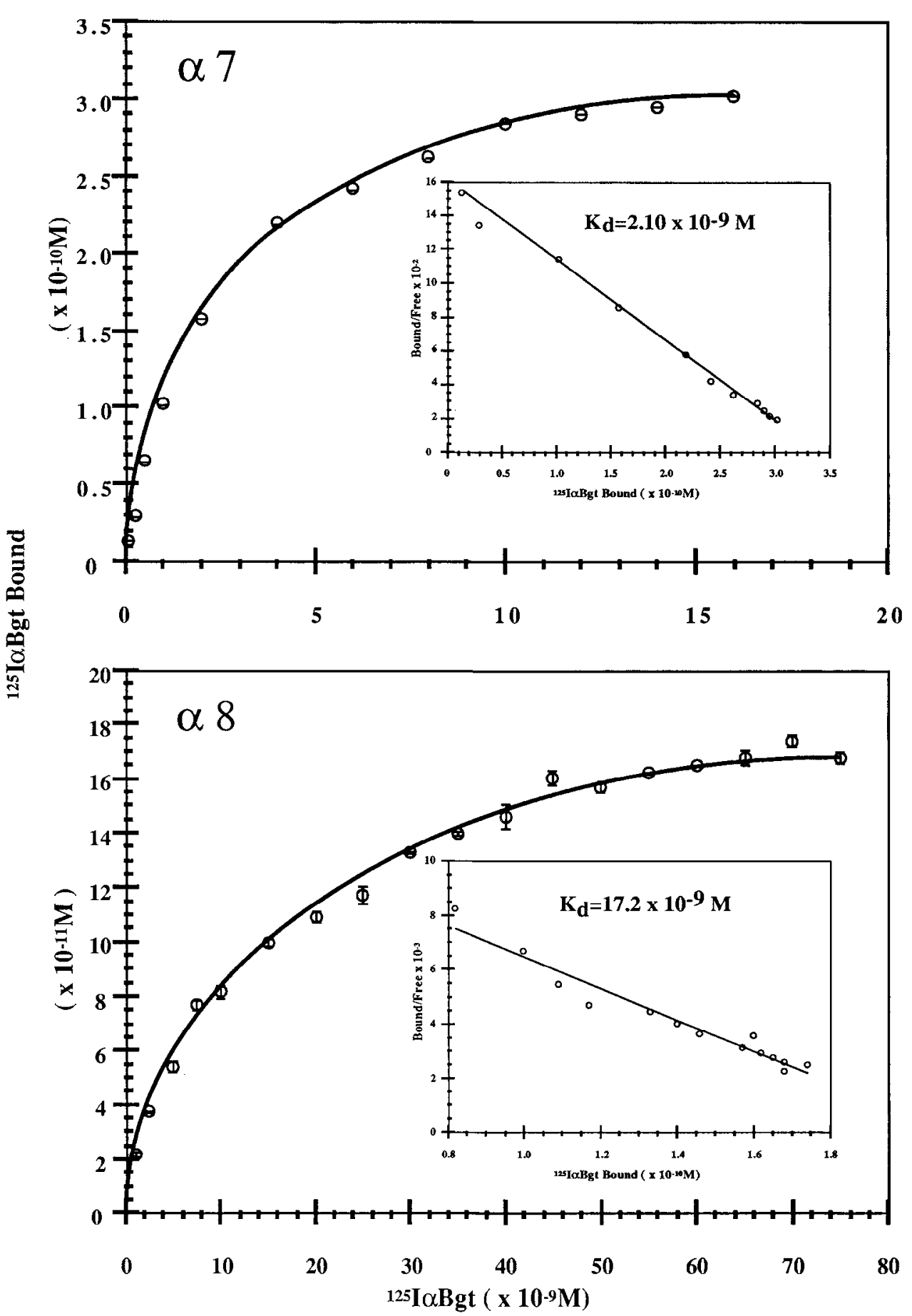

subtype containing only $\alpha 8$ subunits in brain as well as somewhat larger amounts of the subtype containing $\alpha 7$ and $\alpha 8$ subunits. However, the preponderant subtype in brain contained only $\alpha 7$ subunits, as previously reported (Schoepfer et al., 1990). In contrast, the predominant subtype in retina contained only $\alpha 8$ subunits, while the other two subtypes were present in substantially lower amounts. Thus, the immune precipitation experiments were consistent with the immunohistochemical evidence that $\alpha$ BgtAChRs containing $\alpha 8$ subunits predominate in hatchling chick retina and demonstrated the existence of a previously undetected subtype that includes $\alpha 8$ subunits not in association with $\alpha 7$ subunits. An unexpected finding was that while the relative amounts of the different subtypes were similar in E1 8 and hatchling in brain, this was not the case in retina.
Specifically, there was a marked decrease in the amount of the $\alpha 7$ subtype and a substantial increase in the amount of the $\alpha 8$ subtype in retina from E18 to hatching (Table 3 ). These changes were not studied further at this time.

Immunohistochemical localization of $\alpha B g t A C h R s$ in the INL $\alpha 7$ subunit immunoreactivity was observed in neurons in the inner portion of the INI, (Fig. $1 A, C$ ). Labeling was detected in neurons that ranged in size from 4.5 to $10 \mu \mathrm{m}$ in diameter (Fig. $4 A$ ). In contrast, $\alpha 8$ subunit immunoreactivity was observed in neurons within two distinct regions of the INL (Fig. $1 B, D$ ). In the inner third of the INL, $\alpha 8$ staining was confined to cells that ranged from 4.5 to $10 \mu \mathrm{m}$ in diameter (Fig. $4 B$ ). An analysis of 
Table 2. Measurement of the concentration of $\alpha \mathrm{BgtAChR}$ using two different assays

\begin{tabular}{|c|c|c|c|c|}
\hline \multirow[b]{3}{*}{ Sample } & \multicolumn{4}{|c|}{ Concentration of $\alpha \mathrm{BgtAChR}$ in extracts } \\
\hline & \multicolumn{2}{|l|}{ DFAF Assay } & \multicolumn{2}{|c|}{$\begin{array}{l}\text { Immunoassay using both } \\
\text { mAb } 305 \text { and mAb } 318\end{array}$} \\
\hline & $\begin{array}{l}{ }^{125} \mathrm{I}-\alpha \text { Bgt bound } \\
(\mathrm{cpm} \pm \mathrm{SE})\end{array}$ & $\begin{array}{l}\text { Specific } \\
\text { binding } \\
\text { (nM } \pm \text { SE) }\end{array}$ & $\begin{array}{l}{ }^{125} \mathrm{I}-\alpha \text { Bgt bound } \\
(\mathrm{cpm} \pm \mathrm{SE})\end{array}$ & $\begin{array}{l}\text { Specific } \\
\text { binding } \\
(\mathrm{nM} \pm \mathrm{SE})\end{array}$ \\
\hline E18 brain extract & $15,369 \pm 292$ & $2.93 \pm 0.02$ & $17,863 \pm 626$ & $3.05 \pm 0.11$ \\
\hline Blank & $2903 \pm 90$ & & $115 \pm 15$ & \\
\hline E18 brian extract & $22,078 \pm 176$ & $3.40 \pm 0.06$ & $17,597 \pm 677$ & $3.05 \pm 0.12$ \\
\hline Blank & $7132 \pm 257$ & & $148 \pm 10$ & \\
\hline
\end{tabular}

the size and relative frequency of the $\alpha 8$-immunoreactive neurons revealed that cells in the $6-7 \mu \mathrm{m}$ and $7.5-8.5 \mu \mathrm{m}$ size ranges were more numerous than cells in other size classes. However, there were relatively fewer $\alpha 7$-immunoreactive neurons in the 6-7 $\mu \mathrm{m}$ and 7.5-8.5 $\mu \mathrm{m}$ diameter size ranges (Fig. $4 A$ ) than were detected in sections exposed to $\alpha 8$ subunit-specific mAbs.

$\alpha 8$ subunit immunoreactivity was also evident in neurons found within three or four tiers of somata in the outer half of the INL but was absent from the cells at the outer margin of the INL (Figs. $1 B, D ; 6$ ). The labeled cells were generally small, ranging from 4.5 to $6.5 \mu \mathrm{m}$ in diameter, and were present in large numbers (Fig. $5 B$ ). These cells were identifiable as bipolar cells since many of them gave rise to processes that projected outward to the OPL and inward to the IPL. $\alpha 8$ immunoreac-

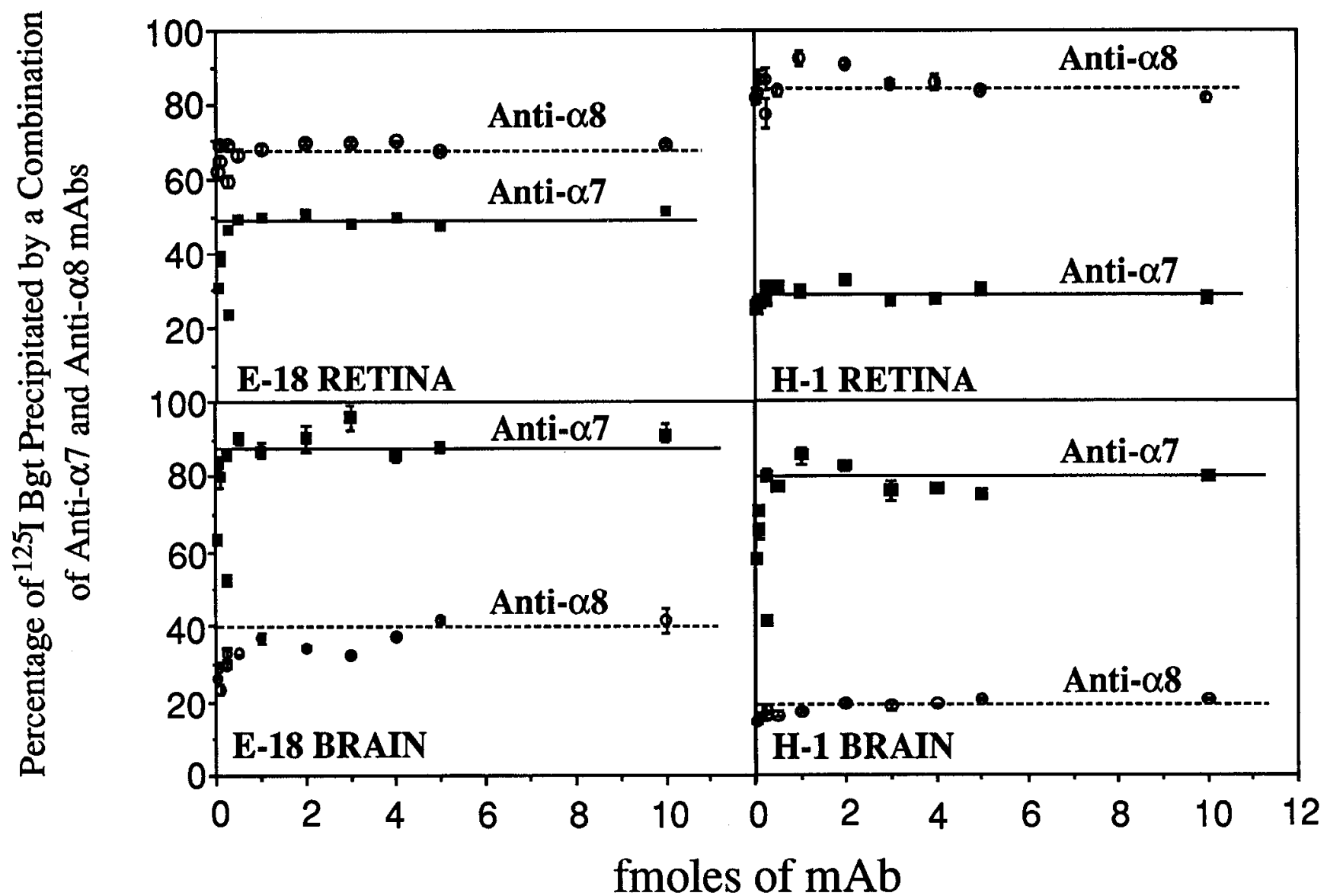

Figure 3. Determination of the fraction of $\alpha \mathrm{BgtAChRs}$ that contain $\alpha 7, \alpha 8$, or both subunits. The maximum fraction of ${ }^{125} \mathrm{I}-\alpha \mathrm{Bgt}$ that could be immunoprecipitated from Triton X-100 extracts of chick retinas and brains with mAb 308 (specific for $\alpha$ BgtAChR $\alpha 8$ subunits), mAb 318 (specific for $\alpha 7$ subunits), or a combination of the two mAbs was determined as described in Materials and Methods. Total $\alpha$ BgtAChR was defined as the maximum that could be precipitated by a combination of both $\mathrm{mAbs}$. The percentage containing only $\alpha 7$ subunits was calculated as the total minus: the percentage precipitated by mAb to $\alpha 8$ subunits. The percentage containing only $\alpha 8$ subunits was calculated as the total minus the percentage precipitated by $\mathrm{mAb}$ to $\alpha 7$ subunits. The percentage containing both $\alpha 7$ and $\alpha 8$ subunits was calculated as the total minus $\alpha 8$ plus $\alpha 7$ subunits. The results of three to four repeats of each panel in this figure were averagcd in Tablc 3 . In this expcriment and one other, 50 nM ${ }^{125}$ I- $\alpha \mathrm{Bgt}$ was used, while in two other instances $35 \mathrm{nM}^{125} \mathrm{I}-\alpha \mathrm{Bgt}$ was used. All of the experiments yielded similar results. This contrasts with the $4 \mathrm{nM}{ }^{125} \mathrm{I}-\alpha \mathrm{Bgt}$ used in previous experiments by Schoepfer et al. (1990) with E18 brain. $\alpha$ BgtAChRs containing only $\alpha 8$ subunits were not detected in these earlier experiments. 
Table 3. Subtypes of $\alpha \mathrm{Bgt}$ binding proteins

\begin{tabular}{|c|c|c|c|c|c|c|}
\hline \multirow[b]{3}{*}{ Subtype } & \multirow{3}{*}{$\begin{array}{l}\begin{array}{l}\text { Subunit } \\
\text { composition }\end{array} \\
\end{array}$} & \multirow{3}{*}{$\begin{array}{l}\text { Possible subunit } \\
\text { arrangement }{ }^{a}\end{array}$} & \multicolumn{4}{|c|}{ Percentage composition $^{b}$} \\
\hline & & & \multicolumn{2}{|c|}{ Brain } & \multicolumn{2}{|c|}{ Retina } \\
\hline & & & E18 & $\mathrm{H} 1$ & E18 & $\mathrm{H} 1$ \\
\hline I & $\alpha_{7}+?$ & & 68 & 74 & 36 & 14 \\
\hline II & $\alpha_{7}+\alpha_{8}+?$ & & 23 & 17 & 23 & 17 \\
\hline III & $\alpha_{8}+?$ & & 9 & 9 & 41 & 69 \\
\hline
\end{tabular}

H1, first day of hatching.

${ }^{\circ}$ This assumes that $\alpha \mathrm{Bgt}$ binding proteins are composed of five subunits, as are $\mathrm{AChRs}$ of muscles and nerves that are homologous in sequence, and that there are two $\alpha$-nonadjacent $\alpha$ subunits as in muscle AChRs.

${ }^{b}$ This is calculated from data in Figure 3 as described in the caption.
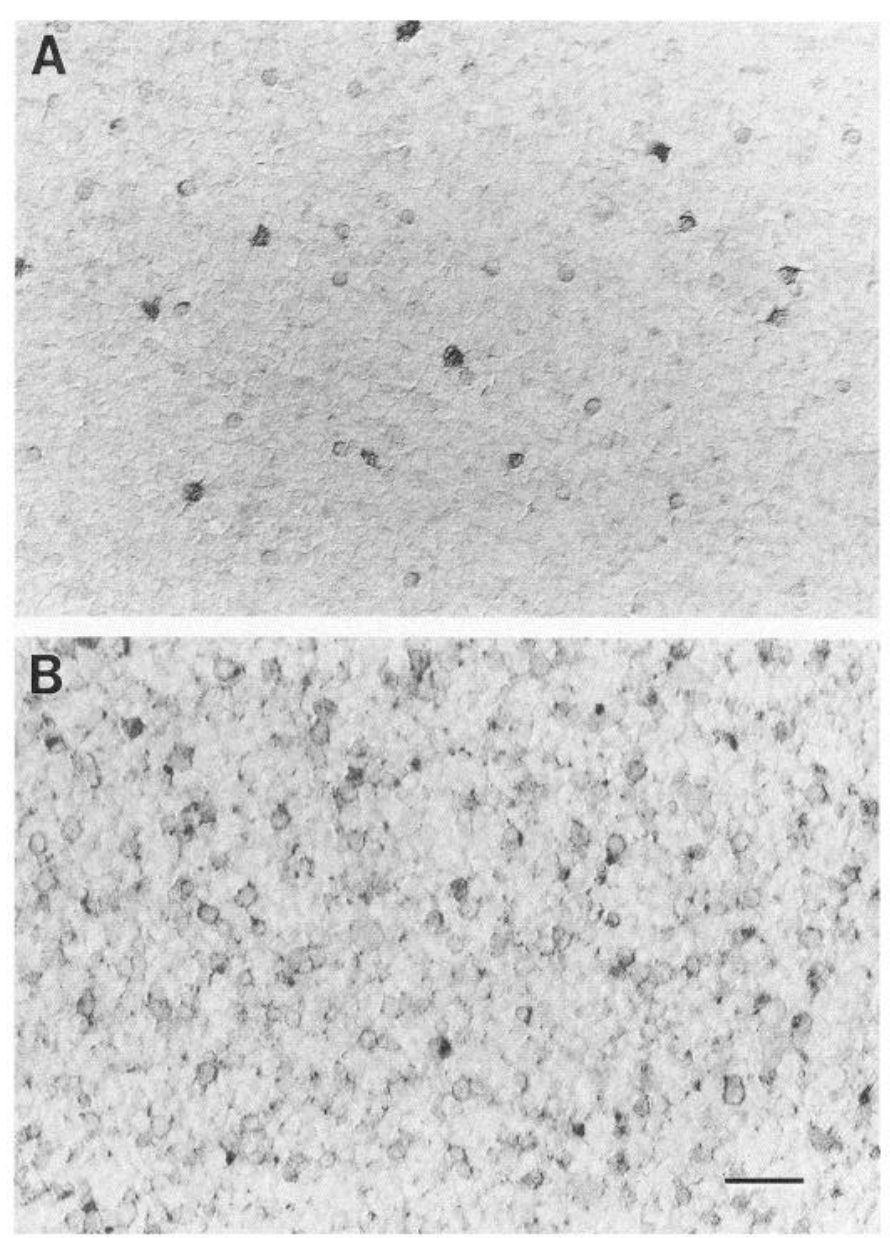

Figure 4. Photographs of chick retina that had been sectioned parallel to the vitreal surface at the level of the inner INL. The section in $A$ was processed using $\mathrm{mAb} 306$, while the section in $B$ was processed using $\mathrm{mAb} 305$. Scale bar, $25 \mathrm{~mm}$.
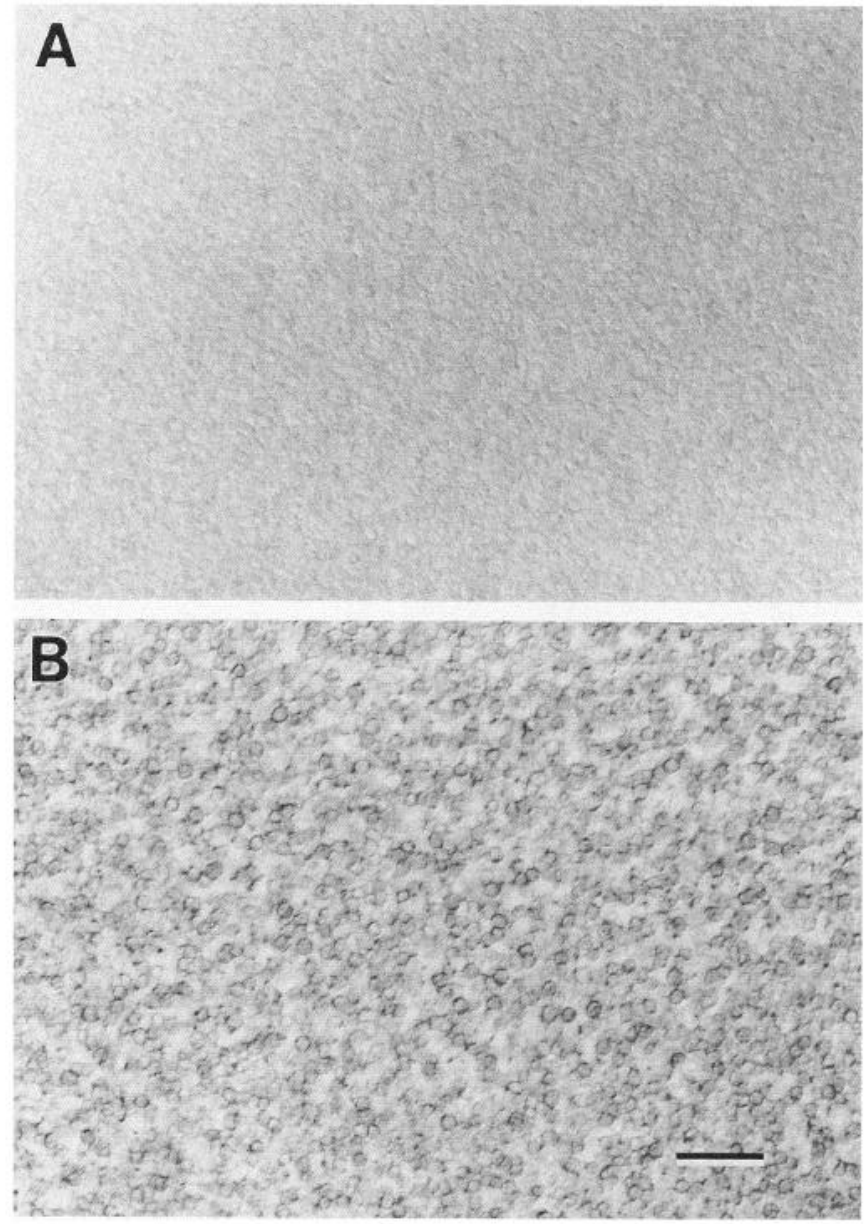

Figure 5. Photographs of chick retina that had been sectioned parallel to the vitreal surface at the level of the outer INL. The section in $A$ was processed using mAb 306 , while the section in $B$ was processed using mAb 305. Nomarski optics allow visualization of both labeled and unlabeled cells. Few, if any, cells in this portion of the retina exhibited $\alpha 7$ immunoreactivity $(A)$, while cells that displayed $\alpha 8$ immunoreactivity were present in high density $(B)$. Scale bar, $25 \mathrm{~mm}$. 


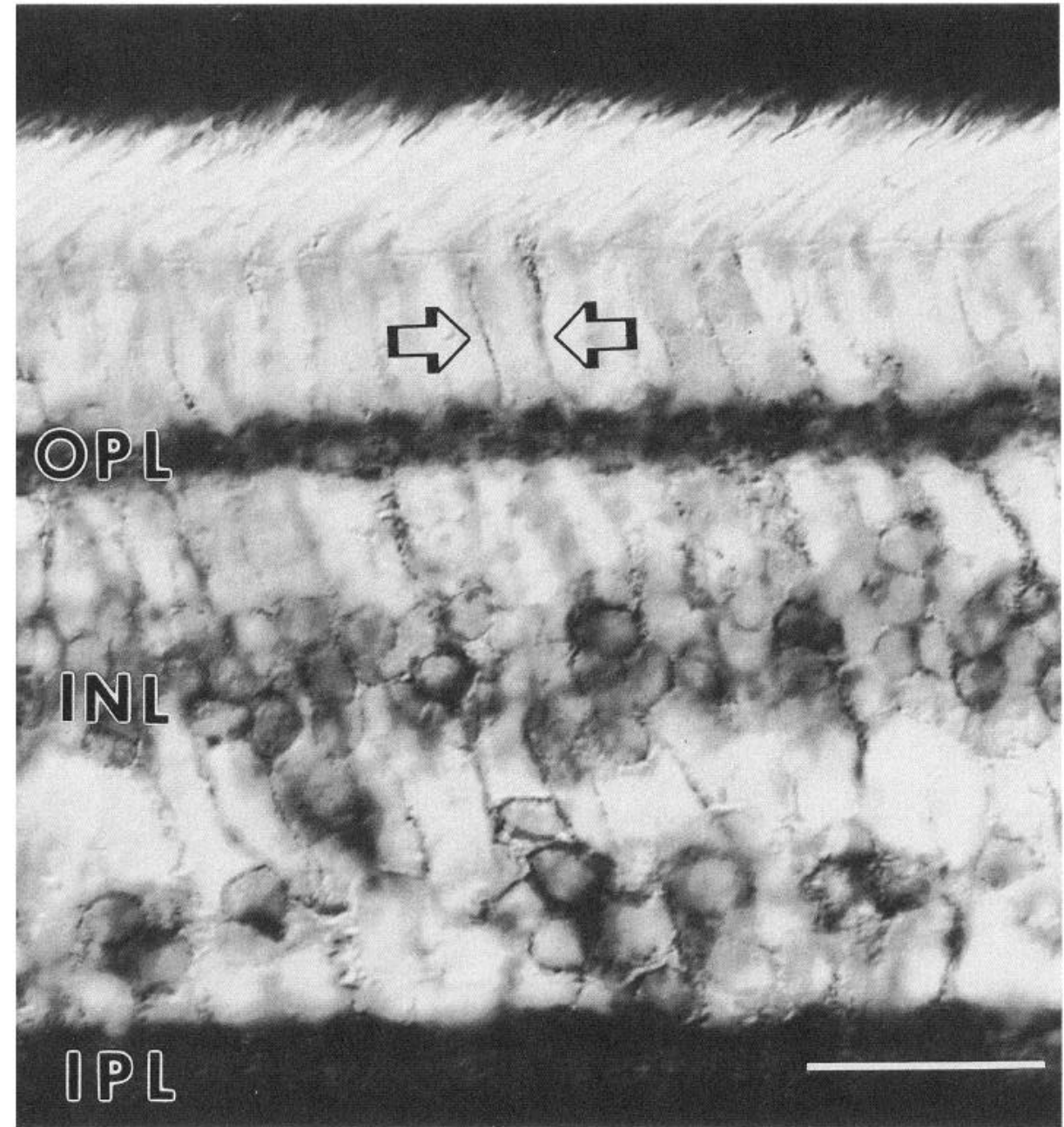

Figure 6. Photograph of a transverse section of chick retina illustrating the distribution of $\alpha 8 \alpha \mathrm{BgtAChR}$ immunoreactivity in the outer retina. The section was processed using $\mathrm{mAb} 305$. The labeled processes that project outward from the OPL are known as Landolt clubs (arrows). These features were not labeled in tissue processed with mAbs against $\alpha 7$ subunits (not shown). Scale bar, $20 \mathrm{~mm}$. tivity within the OPL proper appeared to be restricted to round or oval structures that were distributed in two or three strata (Fig. 6). Many of the bipolar cell processes that projected to the OPL gave rise to small extensions known as Landolt clubs that continued outward to the outer limiting membrane (Fig. 6, arrows). The heavy labeling throughout the IPL obscured the arborizations of individual immunoreactive bipolar cells. $\alpha 7$ immunoreactivity was not detectable in neurons in the outer half of the INL (Fig. 4A) when the mAbs directed against the $\alpha 7$ subunit were used at the same concentrations as those used for the $\alpha 8$ subunit antibodies. However, if the concentration of $\mathrm{mAb}$ directed against $\alpha 7$ subunit was increased, weak staining of some neurons in the outer half of the INL cells was detectable. $\alpha 7$ immunoreactivity in the OPL in these instances was always less intense and more diffuse than the $\alpha 8$ immunoreactivity.

\section{Immunohistochemical localization of $\alpha B g t A C h R s$ in the $G C L$}

$\alpha 7$ and $\alpha 8$ subunit immunoreactivity was detected within cells of the GCL, although the intensity of staining was highly variable (Figs. 1, 7A,B). Because of this variability, we adopted a conservative approach when counting labeled neurons. There were at least $3500-4000 \alpha 8$-immunoreactive cells $/ \mathrm{mm}^{2}$ in the central retina, while in the peripheral retina there were about 1500-2000 labeled cells $/ \mathrm{mm}^{2}$. The neurons that exhibited $\alpha 7$ immunoreactivity were present in lower density than those that displayed $\alpha 8$ immunoreactivity, but were distributed in a similar pattern. There were differences between the sizes of some of the $\alpha 7$ - and $\alpha 8$-immunoreactive neurons in the GCL. In the central retina, cells that exhibited $\alpha 8$ subunit immunoreactivity ranged from 5 to $16 \mu \mathrm{m}$ in diameter while those that displayed $\alpha 7$ subunit labeling ranged from 5 to $21 \mu \mathrm{m}$ in diameter. In the peripheral retina, the $\alpha 7$-immunoreactive cells ranged from 5 to $27 \mu \mathrm{m}$ in diameter while the $\alpha 8$-immunoreactive neurons were $7-30 \mu \mathrm{m}$ in diameter.

In some instances, processes of the labeled neurons could be traced to the inner margin of the IPL. However, because of the intense labeling throughout this layer, we were unable to discern the arborization patterns of individual cells in the GCL. In horizontal sections that included the GCL and optic fiber layer, many labeled cells could be seen to give rise to labeled axons (Fig. $7 B$, arrows) that entered the optic fiber layer and projected to the optic nerve head.

\section{Immunohistochemical localization of $\alpha$ BgtAChRs in the IPL}

$\alpha \operatorname{BgtAChR} \alpha 8$ immunoreactivity was distributed throughout the IPL (Fig. $1 B$ ) but was particularly intense in a band coincident with the innermost portion of lamina 1 and all of lamina 2 . Moderately heavy labeling was also observed in laminae 3 and 4. In contrast, while $\alpha 7$ subunit immunoreactivity was also distributed throughout the IPL (Fig. $1 \mathrm{~A}$ ), labeling was more intense in lamina 3 , in the innermost portion of lamina 4 , and in outer portions of lamina 5 . 
Figure 7. Photographs of chick retina that had been sectioned parallel to the vitreal surface at the level of the GCL. The section in $A$ was processed using $\mathrm{mAb} 306$, while the section in $B$ was processed using $\mathrm{mAb} 305$. The cells that displayed $\alpha 7$ immunoreactivity were present in lower density $(A)$ than those that exhibited than $\alpha 8$ subunit immunoreactivity $(B)$. Many of the labeled cells gave rise to labeled axons that entered the optic fiber layer (arrows). Scale bar, $25 \mathrm{~mm}$.
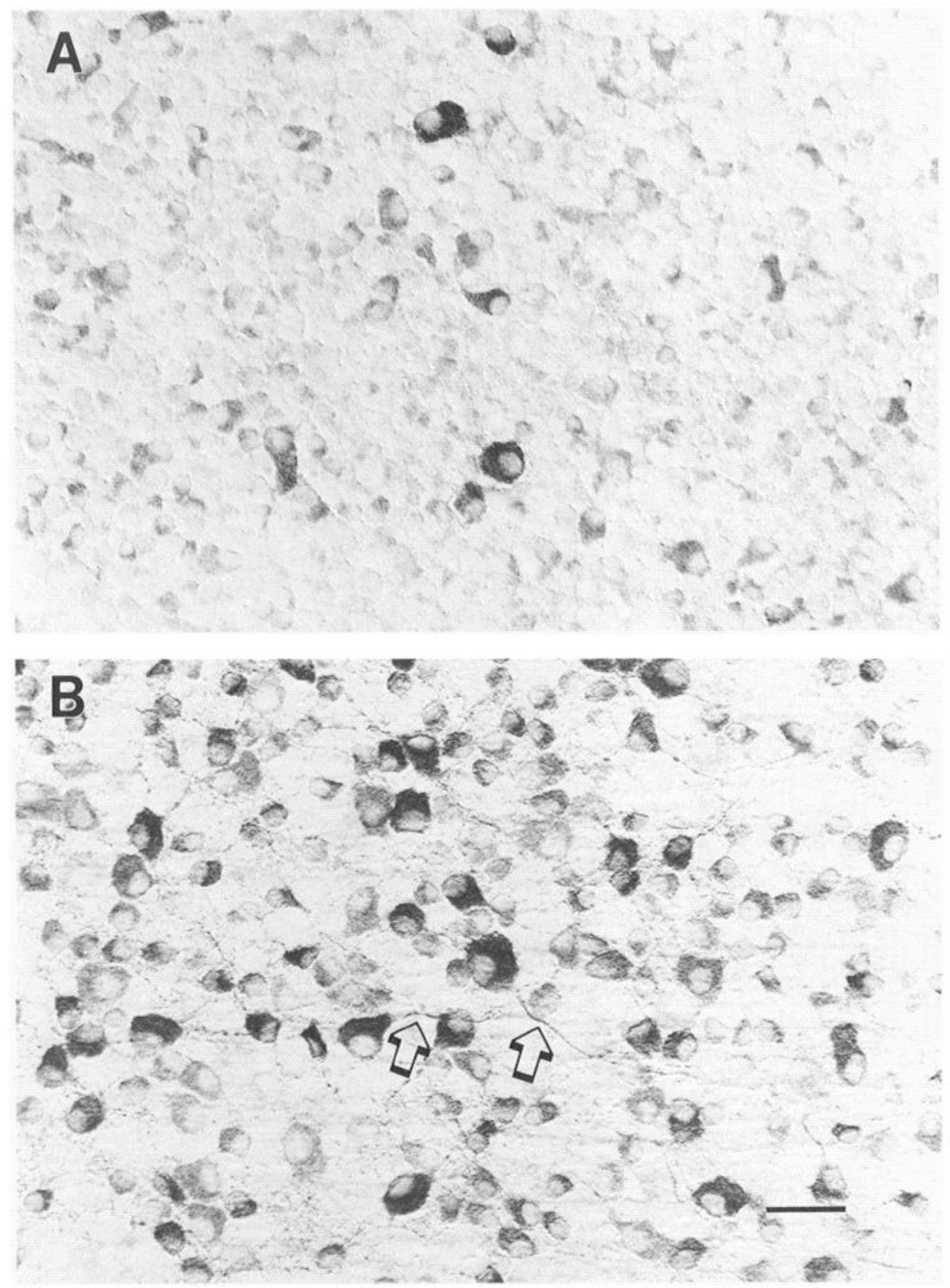

\section{Discussion}

$\alpha B g t A C h R$ subtypes in the retina

All of the $\alpha$ BgtAChRs detected in detergent extracts of chick brains and retinas were shown to contain $\alpha 7$ subunits, $\alpha 8$ subunits, or both. Schoepfer et al. (1990) reported that more than $75 \%$ of all $\alpha$ BgtAChRs in E1 8 chick brain have $\alpha 7$ subunits but no $\alpha 8$ subunits while roughly $15 \%$ have both $\alpha 7$ and $\alpha 8$ subunits. Thus, two subtypes were defined: the " $\alpha 7$ " subtype and the " $\alpha 7 \alpha 8$ " subtype. A third subtype that includes $\alpha 8$, but no $\alpha 7$, subunits was not detected in chick brain. By using a higher concentration of ${ }^{125} \mathrm{I}-\alpha \mathrm{Bgt}$, we have now been able to detect a subtype, termed " $\alpha 8$," which contains $\alpha 8$ subunits, either alone or in conjunction with one or more other, as yet unidentified subunits. This subtype constitutes $9 \%$ of the $\alpha$ BgtAChRs in hatchling chick brain and $69 \%$ of $\alpha$ BgtAChRs in hatchling chick retina. The $\alpha 8$ subtype, together with the $\alpha 7 \alpha 8$ subtype, com- prises roughly $86 \%$ of all $\alpha$ BgtAChRs found in hatchling chick retina. Thus, the retina and brain differ not only in the expression of the $\alpha 8$ subtype, but also in the relative abundance of the $\alpha 7$ and $\alpha 7 \alpha 8$ subtypes. This finding is reminiscent of previous reports that the major nAChR subtype in chick brain has the subunit composition of $(\alpha 4)_{2}(\beta 2)_{3}$ (Anand et al., 1991) and a minor brain $\mathrm{nAChR}$ subtype includes $\alpha 3$ subunits (Wada et al., 1989; Morris et al., 1990; Whiting et al., 1991). In contrast, the nAChR subtype that incorporates $\alpha 3$ subunits is the predominant subtype found in chick retina and ciliary ganglion (Halvorsen and Berg, 1990; Whiting et al., 1991). The $\alpha 8$ subtype is characterized by a much lower affinity for $\alpha$ Bgt than the $\alpha 7$ subtype. This difference in pharmacological characteristics (and others) is also exhibited by $\alpha$ BgtAChRs expressed from $\alpha 7$ and $\alpha 8$ cDNAs (R. Anand and J. Lindstrom, unpublished observations). 


\section{Labeled neurons in the INL and GCL}

The somata and dendrites of selected populations of bipolar, amacrine, and ganglion cells displayed $\alpha$ BgtAChR immunoreactivity. The observation that the receptor immunoreactivity was distributed throughout the neurons is consistent with previous findings in retina and in other portions of the nervous system. For example, nAChR and $\alpha$ BgtAChR subunit immunoreactivity has been described in cell bodies, as well as dendrites, of chick brain and retinal neurons (Keyser et al., 1988; Whiting et al., 1991; Britto et al., 1992). Similarly, Jacob et al. (1986) and Stollberg and Berg (1987) reported that many mAb 35 binding sites (mAb 35 is an antibody that recognizes the main immunogenic region of muscle nAChRs) in chick ciliary ganglion were intracellular. These and other examples suggest that the distribution of receptors throughout nonsynaptic portions of neurons is widespread. Such observations may reflect the detection of $\mathrm{AChRs}$ during synthesis, transport, or destruction or, alternatively, extrasynaptic AChRs whose physiological roles are, at present, unknown.

The neurons in the outer half of the INL that displayed $\alpha 8$ immunoreactivity were identifiable as bipolar cells because of their position and the appearance of the inwardly directed axons and the outwardly directed dendrites. The staining throughout the IPL obscured the axons and their terminations, thus preventing a determination of which of the eight bipolar cell subtypes described in the avian retina (Mariani, 1987) display $\alpha \mathrm{BgtAChR}$ immunoreactivity. In many instances, the labeled dendrites gave rise to Landolt clubs that extended from the OPL to the outer limiting membrane. These processes, whose function is unknown, are found primarily in the retinas of nonmammalian vertebrates, although there is one report of such processes in the retina of a prototherian mammal (Young and Vaney, 1990). The fact that cells in this portion of the retina exhibited weak $\alpha 7$ subunit immunoreactivity only when the antibodies were used at much higher concentrations is consistent with the possibility that small amounts of this subunit may be present in some of these cells.

The position of the $\alpha 7$ - and $\alpha 8$-immunoreactive somata in the inner INL and the absence of outwardly directed processes indicate that the majority of these neurons were probably amacrine cells. The observation that cells in particular size classes exhibited $\alpha 8$ immunoreactivity than $\alpha 7$ immunoreactivity suggests that partially overlapping, but not identical, populations of cells cxpress the $\alpha 7$ and $\alpha 8$ subunits.

Many of the cells in the GCL that exhibited $\alpha 7$ or $\alpha 8$ immunoreactivity were identifiable as ganglion cells since they gave rise to labeled axons. However, we cannot exclude the possibility that some of the labeled cells in this layer were amacrine cells, nor do we know precisely what proportion of the labeled cells were ganglion cells. The $\alpha$ BgtAChR-positive cells were present in highest density in the central retina near the tip of the pecten but decreased in density near the periphery. The neurons that exhibited $\alpha 7$ immunoreactivity were present in lower density than those that displayed $\alpha 8$ immunoreactivity, but were distributed in a similar pattern. Such a change in cell density with increasing eccentricity is characteristic of ganglion cells as a whole in the chick retina (Ehrlich, 1981).

The $\alpha 7$-immunoreactive neurons in the GCL in the central retina ranged from 5 to $21 \mu \mathrm{m}$ in diameter, while the $\alpha 8$-immunoreactive cells ranged from 5 to $16 \mu \mathrm{m}$ in diameter. In the peripheral retina, the range of sizes of the $\alpha 7$ - and $\alpha 8$-immunoreactive cells was essentially the same. This suggests that some populations of large neurons in the central retina may express $\alpha 7$, but not $\alpha 8$, subunits.

The observation that bipolar, amacrine, and ganglion cells in the chick retina exhibit $\alpha \mathrm{BgtAChR}$ immunoreactivity is consistent with the results of previous studies of $\alpha \mathrm{Bgt}$ binding in the retinas of goldfish, turtle, chick, and mouse. For example, James and Klein (1985) reported that in turtle retina only bipolar cells bound $\alpha$ Bgt. In contrast, Vogel et al. (1977) observed that bipolar and amacrine synapses in the chick retina were labeled with peroxidase-labeled $\alpha$ Bgt. Zucker and Yazulla (1982) found that peroxidase-conjugated $\alpha \mathrm{Bgt}$ binding in the IPL of goldfish retina was always associated with synapses in which an amacrine cell process was the presynaptic element while the postsynaptic element was either an amacrine, ganglion, or bipolar cell. However, peroxidase-conjugated $\alpha \mathrm{Bgt}$ binding in the IPL of mouse retina was confined to amacrine-bipolar cell contacts and amacrine-amacrine cell contacts (Pourcho, 1979). Labeling was not detected at synapses in which a bipolar cell was the presynaptic element. In none of these studies was the identity of the presynaptic amacrine cells known.

\section{Labeling in the OPL}

There are reportedly six types of photoreceptors in the avian retina, and their terminals are distributed in three layers in the OPL (Mariani, 1987). The round or oval structures that were visible in the OPL in transverse sections of retina following exposure to antibodies against $\alpha 8$ subunits appeared to be distributed in two or three layers, suggesting that these features may represent clusters of labeled bipolar cell dendrites. Previous studies by Yazulla (1979), who found that $\alpha$ Bgt binding sites in the OPL were associated with a plexus of small processes bounded distally by photoreceptor terminals and proximally by a large dendrite, provide support for this suggestion. However, the $\alpha \mathrm{Bgt}$ binding sites in the OPL were not consistently associated with identifiable synaptic structures (Yazulla, 1979), rendering the interpretation of these findings difficult at best.

Other findings reported by Yazulla (1979) demonstrate that $\alpha \mathrm{Bgt}$ binding in the OPL of pigeons differs in some respects from that observed in other species. The binding of $\alpha \mathrm{Bgt}$ in the IPL and OPL of goldfish and turtle retina was eliminated by treatment with $10^{-5} \mathrm{M}$ nicotine. However, while $\alpha \mathrm{Bgt}$ binding in the IPL of avian retina was blocked by similar concentrations of nicotine, the binding in the OPL was unaffected by nicotine at concentrations as high as $10^{-3} \mathrm{M}$ (Yazulla, 1979). Drug competition assays indicated that this resistance to nicotine block was not a result of nicotine uptake or enzymatic degradation but rather reflected a property of the binding site itself (Yazulla, 1979). This implied that there are at least two pharmacologically distinct forms of the binding site in pigeon retina. Our observation of intense $\alpha 8$ subunit immunoreactivity in the OPL suggests that one of the known $\alpha$ BgtAChR subtypes that incorporate $\alpha 8$ subunits, or an as yet unidentified $\alpha 8$ subtype, may display this resistance to nicotine block.

\section{Labeling in the IPL}

The observation that $\alpha \mathrm{BgtAChR}$ immunoreactivity was distributed throughout the IPL demonstrates that many different cell types with diverse patterns of arborization express these proteins. The differences between the patterns of $\alpha 7$ and $\alpha 8$ immunoreactivity within the IPL reflect the differences in arborization patterns of the subpopulations of neurons that express each subunit. Intense $\alpha 8$ labeling was coincident with the 


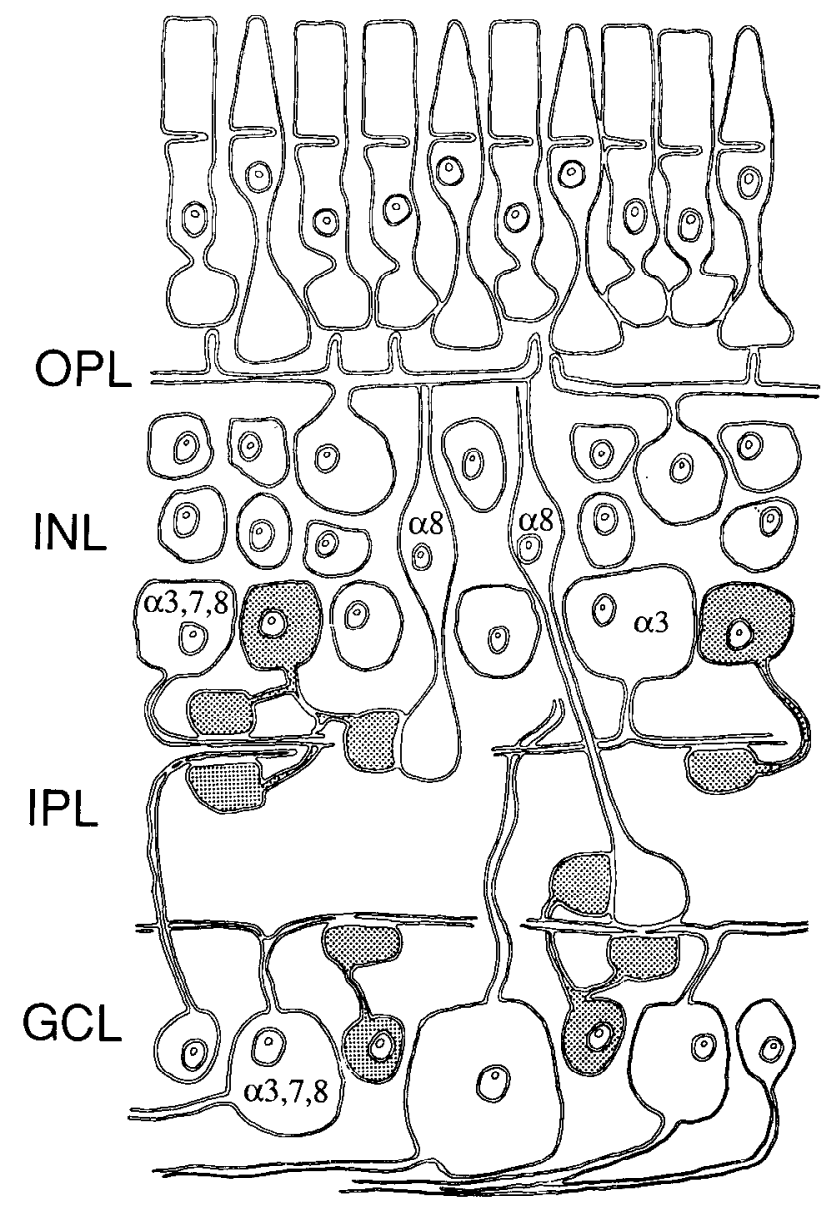

Figure 8. Summary diagram illustrating the distribution of $\mathrm{nAChR}$ ACh binding subunit and $\alpha \mathrm{BgtAChR}$ subunit immunoreactivity in the chick retina. Amacrine, ganglion, and bipolar cells exhibit $\alpha$ BgtAChR immunoreactivity. In contrast, amacrine, ganglion, and displaced ganglion cells (large cell labeled $\alpha 3$ ) are labeled following exposure to antibodies against $n A C h R$ subunits. The cholinergic amacrine cells are indicated by shading, and possible contacts between them and the receptorcontaining cells are illustrated.

inner portion of lamina 1 and all of lamina 2, while a second, less intensely labeled band included most of lamina 4 . In contrast, $\alpha 7$ immunoreactivity was intense in lamina 4 , moderate in laminae 3 and 5, and weaker throughout the remainder of the IPL. The intense $\alpha 8$ immunoreactivity in laminae 1, 2, and 4 and $\alpha 7$ immunoreactivity in lamina 4 were in register with the arborizations of cells that exhibit $\mathrm{nAChR}$ immunoreactivity (Keyser et al., 1988) and those of ChAT-containing cells (Millar et al., 1987; Spira et al., 1987). This finding is consistent with the possibility that $\alpha \mathrm{BgtAChRs}$ in some retinal neurons function as nAChRs and that the $\alpha \mathrm{BgtAChR}$-containing cells that arborize in these laminae receive cholinergic input. However, there is evidence that $\alpha \mathrm{BgtAChRs}$ may bind other ligands in some portions of the nervous system. For example, Quik et al. (1991) demonstrated that the peptide thymopoietin competes for $\alpha \mathrm{Bgt}$ binding sites in rat brain. In addition, $\alpha \mathrm{Bgt}$ has been shown to compete for substance $\mathbf{P}$ binding sites in rat brain (Utkin et al., 1989). However, the degree to which these findings are physiologically significant is uncertain.

The significance of the diffuse labeling observed throughout the remainder of the IPL is unclear. Zucker and Yazulla (1982) reported that $16 \%$ of the peroxidase-conjugated $\alpha \mathrm{Bgt}$ binding sites in the IPL of goldfish retina were associated with synapses while the remaining $84 \%$ were not associated with synaptic structures. Similarly, the $\alpha 7$ and $\alpha 8$ immunoreactivity distributed throughout much of the IPL of the chick retina may represent $\alpha$ BgtAChRs not associated with synapses. The category of "nonsynaptic" $\alpha$ BgtAChRs could include proteins in transit from cell bodies to their dendritic terminals.

\section{$\alpha B g t A C h R s$ and $n A C h R s$ in the retina}

The distribution of $\mathrm{AAChR} A \mathrm{Ch}$ binding subunit immunoreactivity in the chick retina is different, in some respects, than the distribution of $\alpha \mathrm{BgtAChR}$ subunit immunoreactivity, and this is summarized diagrammatically in Figure 8 . The shaded cells represent cholinergic amacrine cells, and examples of the possible contacts between them and the receptor-containing cells are illustrated. Whereas amacrine, ganglion, and bipolar cells exhibit $\alpha$ BgtAChR immunoreactivity, amacrine, ganglion, and displaced ganglion cells (Fig. 8, large cell labeled $\alpha 3$ ) were labeled following exposure to antibodies against nAChR subunits (Keyser et al., 1988; Whiting et al., 1991). In contrast to the widespread distribution of $\alpha \mathrm{BgtAChR}$ labeling in the IPL, nAChR immunoreactivity was restricted to the two bands within which the cholinergic amacrine cells arborize (see Fig. 1). Furthermore, $\mathrm{nAChR}$ immunoreactivity was absent from the OPL. Differences between the distribution of $\alpha \mathrm{Bgt}$ binding sites and nAChRs in both avian and rodent brains have been reported as well (Marks and Collins, 1982; Clarke et al., 1985; Swanson et al., 1987; Watson ct al., 1988; Britto et al., 1992).

\section{Conclusion}

Previous studies have demonstrated that $\alpha \mathrm{BgtAChRs}$ in the retina are pharmacologically heterogeneous. For example, only $10 \%$ of the $\alpha \mathrm{Bgt}$ binding in the chick retina is competed for by neuronal bungarotoxin (Loring et al., 1989). Moreover, as discussed previously, nicotine blocks $\alpha$ Bgt binding in the IPL but not in the OPL of avian retina (Yazulla, 1979). The correlation between this pharmacological heterogeneity and the three immunologically defined $\alpha$ BgtAChR subtypes identified in chick retina and brain is not clear. Whilc the $\alpha 7 \alpha \mathrm{BgtAChR}$ subunit has been shown to form a channel that responds to $\mathrm{ACh}$ in Xenopus oocytes (Couturier et al., 1990), similar studies with the $\alpha 7 \alpha 8$ subtype and the $\alpha 8$ subtype have, to date, not detected functional channels (R. Anand and J. Lindstrom, unpublished observations). Data from such studies and subsequent pharmacological characterization will be necessary for us to address the question of whether specific $\alpha \mathrm{BglAChRs}$ subtypes subserve unique functional roles in the nervous system.

\section{References}

Ames A, Pollen DA (1969) Neurotransmission in central nervous tissue: a study of isolated rabbit retina. J Neurophysiol 32:424-442.

Anand R, Conroy W, Schoepfer R, Lindstrom J (1991) Neuronal nicotinic acetylcholine receptors expressed in Xenopus oocytes have a pentameric quaternary structure. J Biochem 266:11192-11198.

Ariel M, Daw NW (1982a) Effects of cholinergic drugs on receptive field properties of rabbit retinal ganglion cells. J Physiol (Lond) 324: 135-160.

Ariel M, Daw NW (1982b) Pharmacological analysis of directionally sensitive rabbit retinal ganglion cells. J Physiol (Lond) 324:161-185.

Ballivet M, Nef P, Couturier S, Rungger D, Bader CR, Bertrand D, Cooper E (1988) Electrophysiology of a chick neuronal nicotinic acetylcholine receptor expressed in Xenopus oocytes after cDNA injection. Neuron 1:847-852. 
Boulter J, Evans K, Goldman D, Martin G, Treco D, Heinemann S, Patrick J (1987) Isolation of a cDNA clone coding for a possible neural nicotinic acetylcholine receptor $\alpha$-subunit. Nature 319:368-374.

Britto LRG, Keyser KT, Lindstrom JM, Karten HJ (1992) Immunohistochemical localization of nicotinic acetylcholine receptor subunits in the mesencephalon and diencephalon of the chick (Gallus gallus). J Comp Neurol 317:325-340.

Carbonetto S, Fambrough D, Muller K (1978) Nonequivalence of $\alpha$-bungarotoxin receptors and acetylcholine receptors in chick sympathetic neurons. Proc Natl Acad Sci USA 75:1016-1020.

Chiappinelli VA (1985) Actions of snake venom toxins on neuronal nicotinic acetylcholine receptors and other neuronal receptors. Pharmacol Ther 31:1-32.

Clarke PBS, Schwartz SM, Paul CD, Pert CD, Pert A (1985) Nicotinic binding in rat brain: autoradiographic comparison of acetylcholine, $\left[{ }^{3} \mathrm{H}\right]$ nicotine, [ $\left.{ }^{[25} \mathrm{I}\right]-\alpha$-bungarotoxin. J Neurosci 5:1307-1315.

Couturier S, Bertrand D, Matter J-M, Hernandez M-C, Bertrand S, Millar N, Valera S, Barkas T, Ballivet M (1990) A neuronal nicotinic acetylcholine receptor subunit (alpha 7) is developmentally regulated and forms a homo-oligomeric channel blocked by alpha bungarotoxin. Neuron 5:847-856.

Ehrlich D (1981) Regional specialization of the chick retina as revealed by the size and density of neurons in the ganglion cell layer. J Comp Neurol 195:643-657.

Gotti C, Esparis Ogando A, Hanke W, Schlue R, Moretti M, Clementi $F$ (1991) Purification and characterization of an $\alpha$-bungarotoxin receptor that forms a functional nicotinic channel. Proc Natl Acad Sci USA 88:3258-3262.

Halvorsen S, Berg D (1990) Subunit composition of nicotinic acetylcholine receptors from chick ciliary ganglia: correlation with known gene products. J Neurosci 10:1711-1718.

Jacob MH, Berg DK (1983) The ultrastructural localization of alphabungarotoxin binding sites in relation to synapses on chick ciliary ganglion neurons. J Neurosci 3:260-271.

Jacob MH, Berg DK, Lindstrom JM (1984) A shared antigenic determinant between the Electrophorus acetylcholine receptor and a synaptic component on chick ciliary ganglion neurons. Proc Natl Acad Sci USA 81:3223-3227.

Jacob MH, Lindstrom JM, Berg DK (1986) Surface and intracellular distribution of a putative neuronal nicotinic acetylcholine receptor. J Cell Biol 103:205-214.

James WM, Klein WL (1985) $\alpha$-Bungarotoxin receptors on neurons isolated from turtle retina: molecular heterogeneity of bipolar cells. J Neurosci 5:352-361.

Keyser KT, Hughes TE, Whiting P., Lindstrom JM, Karten HJ (1988) Cholinoceptive neurons in the retina of the chick: an immunohistochemical study of the nicotinic acetylcholine receptors. Vis Neurosci $1: 349-366$.

Lindstrom JM, Einarson B, Tzartos S (1981) Production and assay of antibodies to acetylcholine receptors. Methods Enzymol 74:432-460.

Lipton SA, Frosch MP, Phillips MD, Tauck DL, Aizenman E (1987) Nicotinic antagonists enhance process outgrowth by rat retinal ganglion cells in culture. Science 239:1293-1295.

Loring RH, Aizenman E, Lipton SA, Zigmond RE (1989) Characterization of nicotinic receptors in chick retina using a snake venom neurotoxin that blocks neuronal nicotinic acetylcholine receptor function. J Neurosci 9:2423-2431.

Mariani AP (1987) Neuronal and synaptic organization of the outer plexiform layer of the pigeon retina. Am J Anat 179:25-39.

Marks MJ, Collins AC (1982) Characterization of nicotine binding in mouse brain and comparison with the binding of $\alpha$-bungarotoxin and quinuclidinyl benzilate. Mol Pharmacol 22:554-564.

Masland RH, Ames A (1976) Responses to acetylcholine of ganglion cells in an isolated mammalian retina. J Neurophysiol 32:424-442.

McLane KE, Wu X, Schoepfer R, Lindstrom JM, Conti-Tronconi BM (1991) Identification of sequence segments forming the $\alpha$-bungarotoxin binding sites on two nicotinic acetylcholine receptor $\alpha$ subunits from the avian brain. J Biol Chem 266:11192-11198.

McLane KE, Wu X, Lindstrom JM, Conti-Tronconi BM (1992) Epitope mapping of polyclonal and monoclonal antibodies against two $\alpha$ bungarotoxin binding $\alpha$ subunits from neuronal nicotinic receptors. J Neuroimmunol 38:1 15-128.

McReynolds JS, Miyachi F. (1986) The effect of cholinergic agonists and antagonists on ganglion cells in the mudpuppy retina. Neurosci Res [Suppl] 4:S153-S161.
Millar TJ, Ishimoto I, Chubb IW, Epstein ML, Johnson CD, Morgan IG (1987) Cholinergic amacrine cells of the chicken retina: a light and electron microscope immunocytochemical study. Neuroscience 21:725-743

Morris B, Hicks A, Wisden W, Darlison M, Hunt S, Barnard E (1990) Distinct regional expression of nicotinic acetylcholine receptor genes in chick brain. Mol Brain Res 7:305-315.

Noell WK, Lasansky A (1959) Effects of electrophoretically applied drugs and electric currents on ganglion cells of the retina. Fed Proc 18:115.

Patrick J, Stallcup WB (1977) Immunological distinction between acetylcholine receptor and the $\alpha$-bungarotoxin binding component on sympathetic neurons. Proc Natl Acad Sci USA 74:4689-4692.

Pourcho RG (1979) Localization of cholinergic synapses in mammalian retina with peroxidase-conjugated $\alpha$-bungarotoxin. Vision Res 19:287-292.

Quik M, Babu U, Audhya T, Goldstein G (1991) Evidence for thymopoietin and thymopoietin/ $\alpha$-bungarotoxin/nicotinic receptors within the brain. Proc Natl Acad Sci USA 88:2603-2607.

Ravdin PM, Berg DK (1979) Inhibition of neuronal acetylcholine sensitivity by $\alpha$-toxins from Bungarus multicinctus venom. Proc Natl Acad Sci USA 76:2072-2076.

Schmidt J, Raftery M (1973) A simple assay for the study of solubilize acetylcholine receptors. Anal Biochem 52:349-354.

Schoepfer R, Conroy WG, Whiting P, Gore M, Lindstrom J (1990) Brain $\alpha$ bungarotoxin binding protein cDNAs and $\mathrm{mAbs}$ reveal subtypes of this branch of the ligand-gated ion channel gene superfamily. Neuron 5:35-48.

Schwartz IR, Bok D (1979) Electron microscopic localization of $\left[{ }^{125} \mathbf{I}\right]$ $\alpha$-bungarotoxin binding sites in the outer plexiform layer of the goldfish retina. J Neurocytol 8:53-66.

Spira AW, Millar TJ, Ishimoto I, Epstein ML, Johnson CD, Dahl JL, Morgan IG (1987) Localization of choline acetyltransferase-like immunoreactivity in the embryonic chick retina. J Comp Neurol 260: $526-538$.

Stollberg J, Berg DK (1987) Neuronal acetylcholine receptors: fate of surface and internal pools in cell culturc. J Ncurosci 7:1809-1815.

Straschill M (1968) Action of drugs on single neurons in the cat's retina. Vision Res 8:35-47.

Straschill M, Perwein J (1973) The effect of iontophoretically applied acetylcholine upon the cat's retinal ganglion cells. Pfluegers Arch 339: 289-298.

Swanson LW, Simmons DM, Whiting PJ, Lindstrom JM (1987) Immunohistochemical localization of neuronal nicotinic acetylcholine receptors in the rodent central nervous system. J Neurosci 7:3334-3342.

Utkin YN, Lazakovich EM, Kasheverov IE, Tsetlin VI (1989) $\alpha$-Bungarotoxin interacts with the rat brain tachykinin receptors. FEBS Lett 255:111-115.

Vaney DI (1990) The mosaic of amacrine cells in the mammalian retina. Prog Retinal Res 9:49-100.

Vernallis AB, Conroy WG, Corriveau RA, Halvorsen SW, Berg DK (1991) AChR gene products in chick ciliary ganglia: transcripts, subunits, and receptor subtypes. Soc Neurosci Abstr 17:23.

Vijayaraghavan S, Pugh P, Zhang Z, Rathonz M, Berg D (1992) Nicotinic receptors that bind $\alpha$ bungarotoxin on neurons raise intracellular free $\mathrm{Ca}^{++}$. Neuron 8:353-362.

Vogel Z, Nirenberg M (1976) Localization of acetylcholine receptors during synaptogenesis in retina. Proc Natl Acad Sci USA 73: 1806-1810.

Vogel Z, Maloney GJ, Ling A, Daniels MP (1977) Identification of acetylcholine receptor sites in retina with peroxidase-labeled $\alpha$ bungarotoxin. Proc Natl Acad Sci USA 74:3268-3272.

Wada E, Wada K, Boulter J, Deneris E, Heinemann S, Patrick J, Swanson $\mathrm{L}$ (1989) The distribution of $\alpha 2, \alpha 3, \alpha 4$ and $\beta 2$ neuronal nicotinic receptor subunit mRNAs in the central nervous system: a hybridization histochemical study in the rat. J Comp Neurol 284:314-335.

Watson JT, Adkins-Regan E, Whiting P, Lindstrom JM, Podleski TR (1988) Autoradiographic localization of nicotinic acetylcholine receptors in the brain of the zebra finch (Poephila guttata) J Comp Neurol 274:255-264.

Whiting P, Lindstrom J (1986a) Pharmacological properties of immunoisolated neuronal nicotinic receptor. J Neurosci 6:3061-3069.

Whiting PJ, Lindstrom JM (1986b) Purification and characterization of a nicotinic acetylcholine receptor from chick brain. Biochemistry 25:2082-2093. 
Whiting PJ, Lindstrom JM (1987) Purification and characterization of a nicotinic acetylcholine receptor from rat brain. Proc Natl Acad Sci USA 84:595-599.

Whiting PJ, Schoepfer R, Conroy WG, Gore MJ, Keyser KT, Shimasaki, S, Esch F, Lindstrom J (1991) Differential expression of nicotinic acetylcholine receptor subtypes in the brain and retina. Mol Brain Res 10:61-70.

Yazulla S (1979) Synaptic layers of the retina: a comparative analysis with [125I]- $\alpha$-bungarotoxin. In: Neural mechanisms of behavior in the pigeon (Granda AM, Maxwell JH, eds), pp 353-369. New York: Plenum.
Yazulla S, Schmidt J (1976) Radioautographic localization of ${ }^{12 s} \mathrm{I}-\alpha-$ bungarotoxin binding sites in the retina of goldfish and turtle. Vision Res 16:878-880.

Yazulla S, Schmidt J (1977) Two types of receptors for $\alpha$-bungarotoxin in the synaptic layers of the pigeon retina. Brain Res 138:45-47.

Young HM, Vaney DI (1990) The retinae of prototherian mammals possess neuronal types that are characteristic of non-mammalian retinae. Vis Neurosci 5:61-66.

Zucker C, Yazulla S (1982) Localization of synaptic and nonsynaptic nicotinic acetylcholine receptors in the goldfish retina. J Comp Neurol 204:188-195. 